\title{
Transfer Pusat dan Upaya Pendapatan Asli Daerah (Studi kasus Kabupaten/Kota di Kalimantan Barat)
}

\author{
Metasari Kartika* \\ Universitas Tanjungpura
}

\begin{abstract}
This study aims to obtain empirical evidence the impact of intergovernmental transfers on local revenue effort. This study uses unbalanced panel data from 14 Regency / Municipality in West Kalimantan Province during the period 2001 to 2009.The research concluded that (1) There are differences in the local revenue capacity in the Regency/Municipality West Kalimantan Province, causing the local revenue efforts was different, (2) On average in the Regency / Municipality West Kalimantan Province, DAU and DBH tax (unconditional transfers ) has a positive and significant effect on local revenue effort, (3) On average in the Regency / Municipality West Kalimantan Province, DAK (conditional transfers) has a negative and significant effect on local revenue effort.
\end{abstract}

Keywords: Local Revenue Capacity, Local Revenue Effort, Conditional Transfers, Unconditional Transfers.

\section{PENDAHULUAN}

Desentralisasi merupakan suatu cara untuk mencapai tujuan dalam memaksimalkan kesejahteraan masyarakat, khususnya dalam rangka memberikan pelayanan umum yang lebih baik dan menciptakan proses pengambilan keputusan publik yang lebih demokratis. Desentralisasi dapat diwujudkan dengan pelimpahan kewenangan kepada tingkat pemerintahan di bawahnya untuk melakukan pembelanjaan, kewenangan untuk memungut pajak (taxing power), terbentuknya Dewan dan Kepala Daerah yang dipilih oleh rakyat, dan adanya bantuan dalam bentuk transfer dari Pemerintah Pusat (Machfud, 2002).

Transfer mengakibatkan setiap Pemerintah Daerah memiliki tambahan sumber pendapatan dalam menyediakan pelayanan publiknya. Namun, bukan berarti transfer membuat pemerintah daerah mengenyampingkan Pendapatan Asli Daerah. Pada dasarnya prinsip transfer adalah mengisi celah antara pendapatan dan pengeluaran daerah serta tidak bersifat menggantikan pendapatan pajak yang dikumpulkan oleh daerah (Jha, Woojin, \& Nagarajan, 2011).

\footnotetext{
* Korespondensi: Metasari Kartika, Jurusan Ilmu Ekonomi, Fakultas Ekonomi, Universitas Tanjungpura, Jalan Prof. Dr. H. Hadari Nawawi, Pontianak, Indonesia. Email: metasarikartika@ gmail.com.
} 
Selama ini sistem transfer di Indonesia memiliki arti yang sangat penting karena sebagian besar pengeluaran pemerintah daerah dibiayai oleh Pemerintah Pusat melalui transfer. Hal ini terlihat dari jumlah transfer yang semakin meningkat tiap tahunnya dari pemerintah pusat ke pemerintah daerah.

Jumlah transfer dari pusat ke daerah yang meningkat tiap tahunnya dikarenakan permintaan untuk layanan publik yang disediakan oleh pemerintah pusat dan daerah (misalnya; pendidikan, kesehatan, transportasi dan pelayanan kepolisian) telah berkembang pesat. Namun, pendapatan daerah terutama dari pajak belum mampu mengimbangi pertumbuhan pengeluaran yang diinginkan (Rosen \& Ted, 2010). Selain itu, kendala keuangan masih banyak menyulitkan daerah-daerah di Indonesia yang belum mandiri secara finansial. Dimana daerah masih sangat bergantung pada dana transfer untuk membiayai belanja daerah. Data menunjukkan proporsi Pendapatan Asli Daerah (PAD) hanya mampu membiayai pengeluaran pemerintah daerah paling tinggi sebesar 20\% (Haryo, 2004).

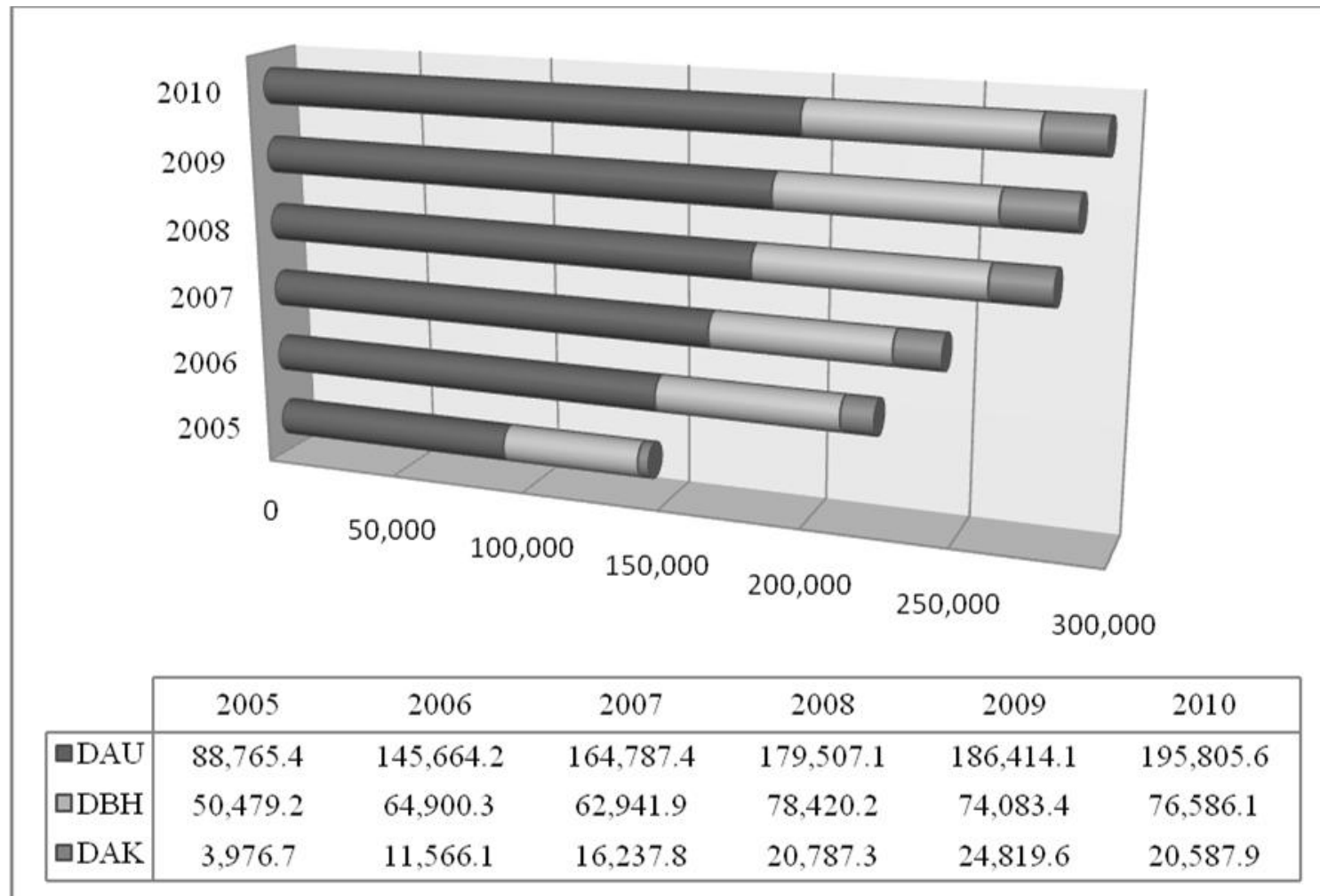

Sumber: Data Pokok APBN 2005-2010, Departemen Keuangan, RI.

\section{Grafik 1. Jumlah Transfer Pusat ke Daerah di Indonesia (Miliar Rupiah)}

Pada Grafik 2 terlihat bahwa di era desentralisasi fiskal masih terdapat ketergantungan keuangan daerah pada transfer pusat, dimana memiliki peranan lebih dari 50\% dalam membiayai kebutuhan daerah di Kabupaten/ Kota Propinsi Kalimantan Barat. Ketergantungan terhadap transfer dari pemerintah pusat juga terjadi di negara berkembang dan transisi ekonomi, transfer juga membiayai sekitar 60 persen dari 
pengeluaran pemerintah daerah di negara-negara anggota Organisation for Economic Co-operation and Development (Shah, 2007).

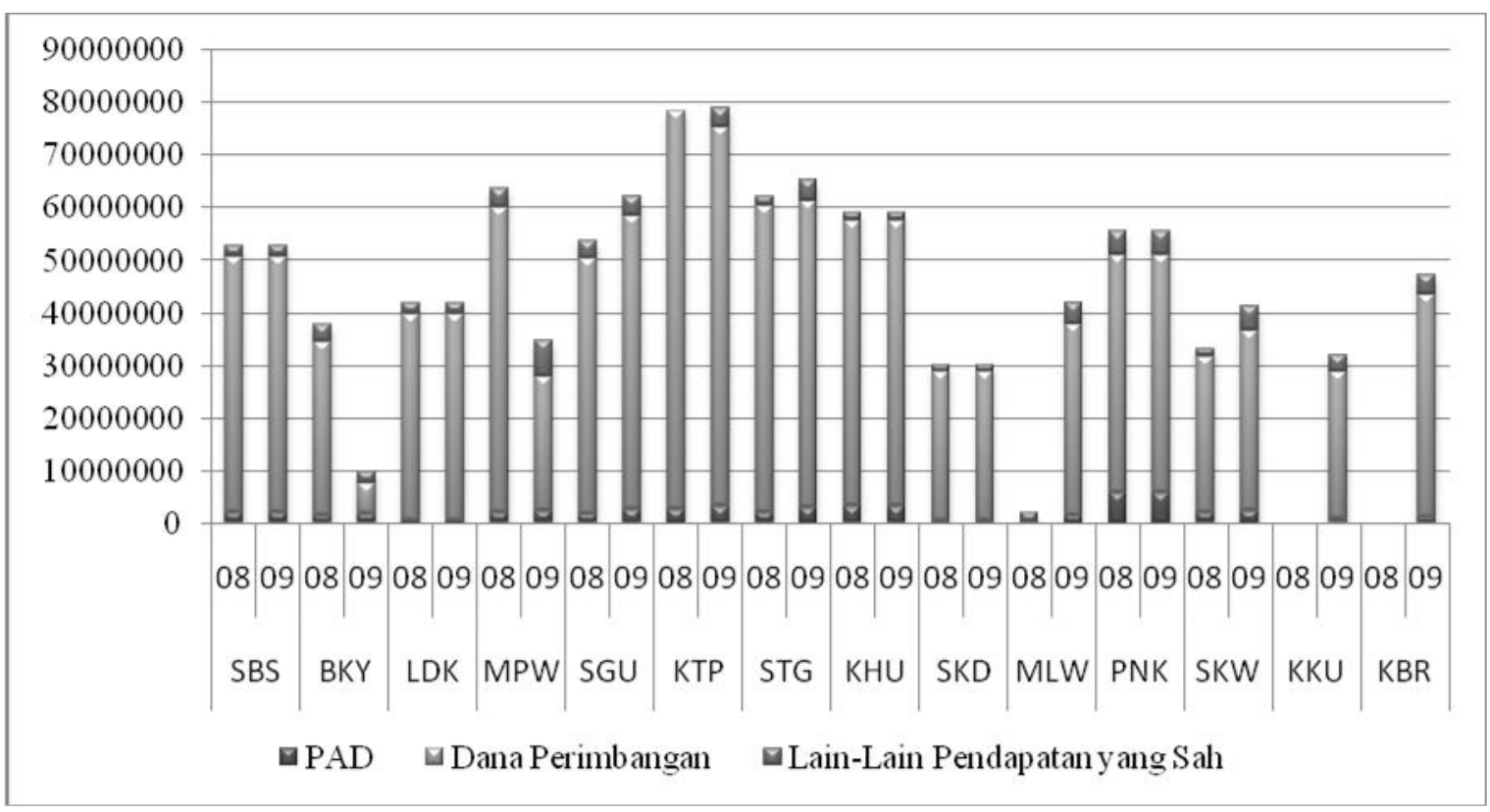

Sumber: data diolah dari BPS $(2009,2010)$.

\section{Grafik 2. Pendapatan Daerah Kabupaten/Kota di Propinsi Kalimantan Barat Tahun 2008- 2009 (Juta Rupiah)}

Jumlah transfer pusat yang besar menandakan kapasitas fiskal daerah masih tidak dapat memenuhi kebutuhan fiskalnya. Kapasitas fiskal yang rendah dapat disebabkan peranan pajak dalam pembiayaan daerah yang sangat rendah dan sangat bervariasi dan juga terjadi karena adanya perbedaan yang cukup besar dalam jumlah penduduk, keadaan geografis (berdampak pada biaya yang relatif mahal), dan kemampuan masyarakat (Machfud, 2002).

Mendominasinya transfer dalam pendapatan daerah diharapkan membuat daerah mampu mengalokasikannya pada sektor-sektor produktif yang mampu mendorong adanya peningkatan investasi yang berdampak pada peningkatan pelayanan publik, sehingga akan meningkatkan kontribusi Pendapatan Asli Daerah (PAD) dalam membiayai kebutuhan daerah.

Sesuai dengan hakikat otonomi daerah dan adanya kebijakan perpajakan dan retribusi, maka setiap daerah memiliki kekuasaan dalam penyelenggaraan pemerintahan dan keuangannya serta pemerintah daerah memiliki wewenang untuk mengelola pajak dan retribusi daerah dalam rangka mewujudkan kemandirian daerah. Adanya kewenangan dan transfer dari pemerintah pusat maka diharapkan meningkatkan upaya pendapatan asli daerah. 
Dalam kaitannya dengan tugas dan fungsi pemerintah daerah yang bebannya dapat diperkirakan dari besarnya pengeluaran, rendahnya PAD serta kecilnya upaya pajak daerah menjadikan pemerintah daerah mempunyai tingkat ketergantungan yang tinggi terhadap dana dari pusat baik dalam bentuk conditional transfers maupun unconditional transfers dalam membiayai pengeluaran daerahnya. Ketergantungan yang tinggi terhadap dana transfer dari pemerintah pusat memiliki potensi untuk mengurangi upaya fiskal daerah, menyimpangnya prioritas belanja, dan meruntuhkan akuntabilitas pejabat daerah akibat kebijakan yang dilakukannya (Chaparro, Smart \& Zapata, 2004).

Oleh karena itu, diperlukanlah upaya dari pemerintah daerah untuk meningkatkan Pendapatan Asli Daerah. Diharapkan dengan PAD yang meningkat akan meningkatkan pula kualitas pelayanan publik, sehingga kemampuan masyarakat meningkat dan pada akhirnya akan meningkatkan kesejahteraan masyarakat dan kemandirian daerah.

\section{TINJAUAN PUSTAKA}

\subsection{Teori Transfer Menurut Rosen \& Gayer (2010).}

Secara umum terdapat dua jenis transfer, yaitu: Transfer bersyarat (Conditional Grants) dan Transfer Tidak Bersyarat (Unconditional Grants). Transfer bersyarat merupakan transfer yang diberikan oleh Pemerintah Pusat kepada Pemerintah Daerah yang pengelolaannya diatur oleh Pemerintah Pusat. Transfer tidak bersyarat merupakan transfer yang diberikan pemerintah pusat kepada daerah yang pengelolaannya diserahkan penuh kepada pemerintah daerah dan diawasi oleh pemerintah pusat. Transfer ini bertujuan untuk pemerataan pendapatan antar daerah dan merupakan dana pendukung pelaksanaan program/ proyek pembangunan yang menjadi prioritas daerah. Pemerintah Pusat juga menetapkan tujuan yang spesifik dalam penggunaan dana transfer bersyarat.

Ada beberapa jenis transfer bersyarat, yaitu: Matching Grants, Matching ClosedEnded Grants, dan Nonmatching Grants. Matching Grants Merupakan transfer dana dari Pemerintah Pusat ke Daerah yang diberikan sesuai dengan dana yang diperlukan oleh Pemerintah Daerah. Dalam transfer Matching Grants pengalokasiannya sudah ditetapkan pada program/proyek tertentu. Transfer Matching Grants memiliki dua pengaruh bagi daerah, yaitu: Pertama, pengaruh pendapatan (income effect), yaitu adanya bantuan menyebabkan peningkatan pendapatan daerah penerima. Kedua, pengaruh substitusi atau harga (price atau substitution effects), yaitu bantuan menyebabkan perubahan pada harga relatif barang publik yang disubsidi terhadap barang publik lain yang tidak disubsidi. Matching Closed-Ended Grants menempatkan batasan seberapa banyak Pemerintah Pusat akan memberikan kontribusi. Nonmatching Grants digunakan untuk membiayai penyediaan barang publik. Bantuan atau tambahan dana akan menggeser atau merubah garis anggaran daerah penerima bantuan. 


\subsection{Teori Transfer Menurut Shah (2007)}

Transfer dapat diklasifikasikan menjadi 2 kategori, yaitu: General-Purpose Transfers (unconditional) dan Specific-Purpose Transfers (conditional or earmarked). General-Purpose Transfers diberikan sebagai dukungan anggaran tanpa syarat yang mengikat. Ciri utama dari transfer General-Purpose Transfers adalah daerah memiliki keleluasaan penuh dalam memanfaatkan dana transfer sesuai dengan pertimbanganpertimbangannya sendiri atau sesuai dengan apa yang menjadi prioritas di daerahnya. Pembagian transfer tanpa syarat biasanya berdasarkan suatu formula tertentu.

Transfer ini dapat dibelanjakan untuk kombinasi barang/jasa publik atau digunakan untuk memberikan keringanan pajak kepada penduduk. Specific-Purpose Transfers digunakan untuk program atau kegiatan yang dianggap penting oleh pemerintah pusat namun kurang dianggap penting oleh daerah. Sehingga dimaksudkan untuk memberikan insentif bagi pemerintah daerah untuk melakukan program atau kegiatan tersebut. Terdiri dari: Nonmatching Transfers dan Matching Transfers. Nonmatching transfers merupakan transfer yang diberikan oleh Pemerintah Pusat kepada Pemerintah Daerah untuk menambah dana penyelenggaraan suatu jenis urusan tertentu tanpa mempertimbangkan bahwa Pemerintah Daerah telah/akan mengalokasikan dananya dalam jumlah besar atau kecil.

Matching Transfers merupakan transfer yang diberikan oleh pemerintah pusat kepada daerah untuk menutup sebagian atau seluruh kekurangan pembiayaan satu jenis urusan tertentu. Jadi disini, pemerintah daerah telah mengalokasikan sejumlah dana dari pendapatan daerahnya untuk penyelenggaraan urusan tersebut. Transfer ini dibedakan menjadi dua jenis, yakni: Open-Ended Matching Grants dan Closed-Ended Matching Grants. Transfer Open-Ended Matching Grants ditujukan untuk menutupi seluruh kekurangan dana yang terjadi. Dengan kata lain, pemerintah daerah tidak ada memiliki batasan dalam menyesuaikan dana transfer dari pemerintah pusat. Pada transfer ClosedEnded Matching Grants terdapat batasan jumlah dana maksimum yang dapat digunakan. Hal ini sangat disukai oleh Pemerintah Pusat, karena walaupun dana yang diberikan sesuai dengan besar proyek, namun setelah besarnya biaya proyek melampaui jumlah tertentu, pemberi bantuan dapat mencukupkan bantuannya.

\subsection{Tax Effort}

Menurut Bird et al. (2008), tax effort merupakan persentase pendapatan pajak dari produk domestik bruto. Adapun indikator dari tax effort adalah rasio dari pendapatan publik terhadap PDB (Produk Domestik Bruto). Menurutnya, konsep tax effort harus dipahami dalam arti luas karena mencakup penerimaan pajak dan bukan pajak termasuk dividen dari perusahaan publik, perpajakan melalui dana stabilisasi, sumber daya daerah setempat serta iuran jaminan sosial. 
Besfamille \& Pablo (2004), Luky (2003), Rosen \& Ted (2010), mengukur tax effort dengan menggunakan rasio antara penerimaan pajak actual terhadap nilai perkiraan yang berasal dari regresi kapasitas pajak. Saruc \& Isa (2008), mendefinisikan tax effort sebagai rasio dari pendapatan lokal dikumpulkan untuk mengukur kekayaan lokal, sehingga upaya pajak daerah $\mathrm{h}_{\mathrm{i}}=$ pendapatan yang dikumpulkan/ perkiraan pendapatan . Rumus dapat diubah sesuai dengan pengukuran kapasitas pendapatan daerah. Tiga metode yang digunakan dalam memperkirakan kapasitas pendapatan: pendekatan ekonomi makro, pendekatan ekonomi mikro dan analisis regresi. Keuntungan umum dari pendekatan ekonomi makro adalah secara ekonomi netral dan independen dari sistem pajak aktual pemerintah daerah (Clark, 1997 dalam Saruc \& Isa, 2008).

Lotz \& Morss dalam Musgrave (1969) menyatakan tiga ukuran tax effort : pertama, rasio pajak terhadap GNP. Kedua, rasio pajak aktual terhadap target pajak (estimasi). Sehingga digunakan persamaan sebagai berikut :

$$
T / Y=a_{1}+b_{1} Y_{p}
$$

Dimana $\mathrm{Y}_{\mathrm{p}}$ adalah pendapatan perkapita. Dan ketiga, menggunakan persamaan yang menambahkan faktor ekspor dan impor. Selanjutnya, Musgrave \& Peggy (1989) menyatakan ukuran perbandingan dari tax effort dapat diturunkan dengan membandingkan rasio aktual pendapatan untuk GNP dari suatu negara. Menggunakan data cross section pada negara berkembang, Musgrave \& Peggy (1989) menggunakan persamaan sebagai berikut :

$$
\frac{T}{Y}=\propto+\alpha Y_{p}+\frac{\beta X}{Y}+\frac{\gamma E}{Y}+\frac{\delta A}{Y}
$$

Dimana:

$$
\begin{array}{ll}
\mathrm{T} & =\text { pendapatan } \\
\mathrm{Y} & =\mathrm{GNP} \\
\mathrm{Yp} & =\mathrm{GNP} \text { perkapita } \\
\mathrm{X} & =\text { ekspor } \\
\mathrm{E} & =\text { output dari industri bahan baku } \\
\mathrm{A} & =\text { output dari pertanian. }
\end{array}
$$

Determinan dari tax effort (Brun, Gérard \& Bertrand, 2010):

Untuk beberapa negara, tax effort dijelaskan oleh kombinasi faktor-faktor struktural dan keputusan kebijakan ekonomi. Dari literatur yang tersedia, ada empat macam faktor yang menjelaskan tax effort dapat dibedakan: Determinan struktural ekonomi, Variabel Kebijakan Makroekonomi, Variabel Kelembagaan, dan Variabel Bantuan. Determinan struktural ekonomi merupakan pendapatan perkapita, kontribusi impor terhadap GDP, kontribusi pertanian terhadap GDP dan kontribusi ekspor minyak dan bijih besi terhadap total ekspor. Variabel Kebijakan Makroekonomi merupakan persentase utang terhadap PDB, inflasi dan nilai tukar riil. Variabel Kelembagaan merupakan korupsi, kualitas birokrasi dan akuntabilitas. 
Variabel Bantuan merupakan aliran bantuan mempengaruhi tingkat pendapatan masyarakat karena merupakan bentuk pengganti pembiayaan (Gupta, 2003; Ouattara, 2006 dalam Brun et al., 2010).

\subsection{Dampak Transfer pada Sistem Desentralisasi}

Flypaper effect merupakan isu yang dominan dalam melihat pengaruh transfer, yang kemudian dikenal dengan First-Generation Theories (Gamkhar \& Anwar, 2007). Fenomena flypaper effect membawa implikasi yang lebih luas bahwa transfer akan meningkatkan pengeluaran pemerintah daerah yang lebih besar daripada penerimaan transfer itu sendiri (Turnbull, 1998 dalam Haryo, 2004). Fenomena flypaper effect dapat terjadi dalam dua versi (Gorodnichenko, 2001 dalam Haryo, 2004). Pertama, merujuk pada peningkatan pajak daerah dan anggaran pengeluaran pemerintah yang berlebihan. Kedua, mengarah pada elastisitas pengeluaran terhadap transfer yang lebih tinggi daripada elastisitas pengeluaran terhadap penerimaan pajak daerah.

Menurut Gamkhar \& Anwar (2007), Second Generation Theories mengungkapkan pengaruh transfer tergantung dari sistem fiskal daerah (misalnya sifat kompetisi pajak, tugas pajak dan jenis fungsi yang dilakukan oleh pemerintah daerah) dan pengaturan kelembagaan merupakan hal yang terpenting untuk menerapkan programprogram pemerintah, sehingga memiliki dampak sebagai berikut: Persaingan Fiskal (Fiscal Competition), Soft Budget Constraint, dan Federal Insurance and The moral Hazard Problem. Persaingan fiskal dalam sistem desentralisasi dapat meningkatkan akuntabilitas pemerintah, tetapi juga dapat menciptakan eksternalitas negative yang mempengaruhi tingkat dan pola kegiatan ekonomi (Oates 2005). Efek negatif persaingan timbul karena pemerintah bersaing untuk sumber daya modal yang relative mobile, dengan mengenakan tarif pajak yang serendah-rendahnya. Transfers dapat membuat soft budget constraint (Kornai, 1979 dalam Gamkhar \& Anwar, 2007) dimana munculnya harapan bahwa pemerintah pusat akan membantu pemerintah daerah yang tidak berhasil. Maka mekanisme yang terbaik untuk menyediakan dukungan pendapatan pemerintah lokal adalah dengan mentransfer basis pajak dari pemerintah pusat ke pemerintah daerah dan pembagian sistem pendapatan dimana pajak yang dihasilkan daerah dapat didistribusikan kembali kepada pemerintah daerah. Federal Insurance and The moral Hazard Problem, transfer dapat berfungsi sebagai bentuk jaminan terhadap guncangan negatif pada perekonomian daerah. Namun, transfer jugadapat menyebabkan masalah moral hazard.

\subsection{Transfer dan Tax Effort.}

Meskipun pemerintah daerah memiliki kapasitas pajak yang sama tetapi dapat mengumpulkan jumlah pajak yang berbeda, dikarenakan beberapa daerah dapat melakukan upaya yang lebih dalam mengumpulkan pajak dibandingkan daerah yang 
lain. Hal ini menunjukkan sejauh mana pemerintah setempat dalam memanfaatkan dasar pengenaan pajak yang tersedia (Gold 1986 dalam Saruc \& Isa,2008).

Jika transfer merangsang upaya pajak maka dapat menghasilkan manfaat efisiensi, dimana dapat memobilisasi pajak daerah sehingga membuat pemerintah daerah tidak lagi bergantung terhadap transfer dari pemerintah pusat. Transfer dari pemerintah pusat dapat digunakan untuk merangsang upaya pajak daerah dengan memberikannya pada pemerintah daerah yang memiliki basis pendapatan melebihi rata-rata nasional dan sanksi apabila pendapatannya di bawah rata-rata nasional (Saruc \& Isa, 2008).

Dalam beberapa studi empiris, seringkali menganalisis hubungan antara upaya pajak daerah dan transfer. Diasumsikan bahwa transfer pemerintah pusat kepada pemerintah daerah adalah penentu signifikan dari upaya pajak daerah. Faktor-faktor lokal seperti kemauan politik, kapasitas administrasi dan kerangka kerja kelembagaan juga menjadi faktor penentu upaya pajak daerah (Saruc \& Isa, 2008).

Literatur tentang Fiscal Federalism menekankan dua penjelasan dari pengaruh transfer pada usaha fiskal. Pertama adalah didasarkan pada assumption of rational benefit maximization. Menurut pendekatan ini, transfer sebagai tambahan pendapatan mengurangi upaya fiskal karena adanya efek substitusi. Hal ini membuat pemerintah daerah mengganti perpajakan lokal dengan transfer (Peterson 1997 dalam Aragón \& Vilma, 2005). Kedua, berdasarkan flypaper effect. Fenomena ini didasarkan pada beberapa bukti empiris menyatakan bahwa pengeluaran pemerintah daerah lebih besar bila dibiayai oleh bantuan tanpa syarat dibandingkan dari sumber daya sendiri (Hines dan Thaler 1995 dalam Aragón \& Vilma, 2005).

\section{METODE PENELITIAN}

Penelitian ini menggunakan pendekatan deskriptif dan kuantitatif. Analisis secara kuantitatif menggunakan model ekonometrika yaitu regresi berganda dengan unbalanced panel data, yang diolah dengan menggunakan program Eviews 6. Penelitian ini fokus pada analisis tentang dampak transfer pusat terhadap upaya Pendapatan Asli Daerah di Kabupaten/Kota Propinsi Kalimantan Barat tahun 2001-2009.

Sebelum membuat model dampak transfer pusat terhadap upaya Pendapatan Asli Daerah maka terlebih dahulu membuat model kapasitas PAD menggunakan konsep kapasitas pajak. Maka digunakan persamaan dengan memodifikasi model dari Piancastelli (2001), Lotz \& Morss dalam Musgrave (1969), Musgrave \& Peggy (1989) yakni:

$$
R C=f(I P C, T R D, A G R)
$$

Persamaan-persamaan diatas dapat dinyatakan dalam model ekonometrika untuk menjelaskan kapasitas PAD di Kabupaten/Kota Propinsi Kalimantan Barat, yaitu : 


$$
R C_{i t}=\beta_{0}+\beta_{1} I P C_{i t}+\beta_{2} T R D_{i t}+\beta_{3} A G R_{i t}+\varepsilon_{i t}
$$

Dimana :

$\mathrm{RC}_{\mathrm{it}}=$ Kapasitas PAD (PAD/PDRB) daerah ke-i, pada tahun $\mathrm{t}$

$\mathrm{IPC}_{\text {it }}=$ PDRB perkapita daerah ke-i, pada tahun $\mathrm{t}$

$\mathrm{AGR}_{\mathrm{it}}=$ Kontribusi sektor pertanian terhadap PDRB daerah ke-i, pada tahun $\mathrm{t}$

$\mathrm{TRD}_{\mathrm{it}}=$ Kontribusi sektor perdagangan terhadap PDRB daerah ke-i, pada tahun $\mathrm{t}$

$\varepsilon_{\text {it }} \quad=$ error term

$\beta_{0} \quad=$ konstanta

$\beta_{1}, \beta_{2}, \beta_{3}=$ parameter regresi yang akan diestimasi

I $\quad=$ kabupaten/kota yang akan diobservasi

$\mathrm{t} \quad=$ periode observasi

Setelah itu, maka akan dapat dihitung nilai upaya Pendapatan Asli Daerah (PAD) dengan definisi yang diungkapkan oleh Besfamille \& Pablo (2004), Saruc \& Isa (2008), Lotz \& Morss dalam Musgrave (1969), maka digunakan rumus sebagai berikut :

$$
R E=\frac{(P A D / P D R B)_{\text {aktual }}}{(P A D / P D R B)_{\text {estimasi }}}
$$

Dimana :

$\mathrm{RE}=$ upaya $\mathrm{PAD},(\mathrm{PAD} / \mathrm{PDRB})_{\text {estimasi }}$ merupakan kapasitas $\mathrm{PAD}$ yang nilainya didapat dari hasil persamaan 4.

Selanjutnya, akan dilihat dampak transfer pusat terhadap upaya PAD dengan modifikasi dari model penelitian Aragón dan Vilma (2005), Nagathan dan K.Jothi (2000), dan Gupta (2007). Variabel dependennya adalah upaya Pendapatan Asli Daerah $(R E)$ dan variabel independen yang akan digunakan adalah conditional transfers (DAK), unconditional transfers (DAU dan DBH Pajak) dan variabel pelayanan publik yang diproksi dengan rasio jumlah pegawai negeri sipil terhadap jumlah penduduk. Maka dapat diperoleh persamaan, dengan faktor-faktor yang mempengaruhinya yaitu :

$$
R E=f(U T, C T, P S) \text {. }
$$

Persamaan-persamaan di atas dapat dinyatakan dalam model ekonometrika untuk menjelaskan upaya Pendapatan Asli Daerah di Kabupaten/Kota Propinsi Kalimantan Barat, yaitu :

$$
R E_{i t}=\alpha_{0}+\alpha_{1} U T_{i t}+\alpha_{2} C T_{i t}+\alpha_{3} P S+\varepsilon_{i t}
$$

Dimana :

$\mathrm{RE}_{\mathrm{it}} \quad=$ Upaya Pendapatan Asli Daerah ke-i, pada tahun $\mathrm{t}$

$\mathrm{UT}_{\mathrm{it}}=\mathrm{DAU}+\mathrm{DBH}$ daerah ke-i, pada tahun $\mathrm{t}$

$\mathrm{CT}_{\text {it }}=$ DAK daerah ke-i, pada tahun $\mathrm{t}$

$\mathrm{PS}_{\mathrm{it}} \quad=$ Rasio jumlah PNS terhadap jumlah penduduk, daerah ke-i, pada tahun $\mathrm{t}$

$\varepsilon_{\text {it }} \quad=$ error term 
$\alpha_{0} \quad=$ konstanta

$\alpha_{1}, \alpha_{2}, \alpha_{3}=$ parameter regresi yang akan diestimasi

$\mathrm{i}=$ kabupaten/kota yang akan diobservasi

$\mathrm{t} \quad=$ periode observasi

\section{TEMUAN DAN PEMBAHASAN}

\subsection{Model Kapasitas Pendapatan Asli Daerah}

Hasil persamaan regresi model kapasitas PAD sebagai berikut :

$$
\begin{aligned}
& \mathbf{R C}_{\mathbf{i t}}=-\mathbf{0 , 1 6 2 6}+\mathbf{0 , 0 1 9 9} \mathbf{L o g} I P C_{i t}+\mathbf{0 , 0 8 3 3} \mathbf{T R D}_{i t}+\mathbf{0 , 0 5 5 5} \mathbf{A G R}_{i t} \\
& \text { t-stat }(-6,9601) \quad(4,3030) * * * \\
& \mathrm{R}^{2}=0,671684 \\
& \text { F-stat } \quad=11,1243 * * * \\
& \text { Keterangan : } * * * \alpha=1 \% .
\end{aligned}
$$

Dari persamaan 8, didapat nilai fixed effect (cross) untuk persamaan kapasitas PAD sebagai berikut :

Tabel 1. Nilai Koefisien Fixed Effect Model Kapasitas PAD Di Kabupaten/Kota Propinsi Kalimantan Barat Tahun 2001 - 2009

\begin{tabular}{clc}
\hline No. & \multicolumn{1}{c}{ Kabupaten/Kota } & Nilai Fixed Effect Pada Intersep \\
\hline 1. & Kab. Sambas & $-0,013174$ \\
2. & Kab. Bengkayang & $-0,009829$ \\
3. & Kab. Landak & $-0,011541$ \\
4. & Kab. Pontianak & 0,012683 \\
5. & Kab. Sanggau & $-0,000544$ \\
6. & Kab. Ketapang & 0,001962 \\
7. & Kab. Sintang & 0,001880 \\
8. & Kab. Kapuas Hulu & $-0,001761$ \\
9. & Kab. Sekadau & $-0,000383$ \\
10. & Kab. Melawi & 0,007740 \\
11. & Kab. Kayong Utara & $-0,001226$ \\
12. & Kab. Kubu Raya & 0,002064 \\
13. & Kota Pontianak & 0,014118 \\
14. & Kota Singkawang & 0,002222 \\
\hline & &
\end{tabular}

Dari hasil regresi, terdapat daerah Kabupaten/Kota yang mempunyai nilai fixed effect positif dapat diartikan bahwa jika variabel-variabel PDRB perkapita, kontribusi sektor perdagangan terhadap PDRB dan kontribusi sektor pertanian terhadap PDRB dianggap konstan maka kapasitas PAD Kabupaten/Kota akan meningkat sebesar nilai fixed effect pada intersep kabupaten/kota tersebut. Perbedaan nilai ini dapat disebabkan 
adanya perkembangan kontribusi persektor terhadap PDRB yang berbeda untuk tiap daerah, perbedaan karakteristik wilayah dan jumlah penduduknya.

Kapasitas PAD dapat menggambarkan kemampuan daerah dalam menggali sumber penerimaannya sehingga diperlukanlah suatu estimasi agar dalam menentukan target penerimaan sesuai dengan kemampuan daerah yang sesungguhnya. Berdasarkan tinjauan literatur, ada dua alternatif cara yang sering dipergunakan dalam estimasi kapasitas fiskal ini. Pertama, dengan menggunakan metode regresi. Kedua, dengan melakukan perhitungan kapasitas pajak daerah secara langsung dengan memperkirakan besarnya basis pajak dan menggunakan tarif pajak efektif (Panggabean, Mahi, Panggabean \& Brodjonegoro, 1999).

Tabel 2. Kapasitas PAD (PAD/ PDRB) Estimasi Kabupaten/Kota di Propinsi Kalimantan Barat

\begin{tabular}{|c|c|c|c|c|c|c|c|c|c|c|c|}
\hline \multirow{2}{*}{ No } & \multirow{2}{*}{$\begin{array}{c}\text { Kabupaten / } \\
\text { Kota }\end{array}$} & \multicolumn{9}{|c|}{ Tahun } & \multirow{2}{*}{$\begin{array}{c}\text { Rata- } \\
\text { rata }\end{array}$} \\
\hline & & 2001 & 2002 & 2003 & 2004 & 2005 & 2006 & 2007 & 2008 & 2009 & \\
\hline 1 & Sambas & 0.003 & 0.003 & 0.004 & 0.005 & 0.006 & 0.006 & 0.007 & 0.007 & 0.007 & 0.005 \\
\hline 2 & Bengkayang & 0.006 & 0.005 & 0.006 & 0.006 & 0.006 & 0.007 & 0.007 & 0.007 & 0.007 & 0.006 \\
\hline 3 & Landak & 0.026 & 0.026 & 0.026 & 0.027 & 0.027 & 0.026 & 0.026 & 0.027 & 0.027 & 0.026 \\
\hline 4 & Pontianak & 0.010 & 0.009 & 0.009 & 0.009 & 0.012 & 0.012 & 0.013 & 0.014 & 0.014 & 0.011 \\
\hline 5 & Sanggau & 0.001 & 0.002 & 0.005 & 0.004 & 0.008 & 0.009 & 0.009 & 0.009 & 0.009 & 0.006 \\
\hline 6 & Ketapang & 0.009 & 0.011 & 0.008 & 0.008 & 0.010 & 0.006 & 0.006 & 0.005 & 0.006 & 0.008 \\
\hline 7 & Sintang & 0.017 & 0.017 & 0.018 & 0.006 & 0.013 & 0.013 & 0.014 & 0.014 & 0.014 & 0.014 \\
\hline 8 & Kapuas Hulu & 0.012 & 0.013 & 0.013 & 0.008 & 0.008 & 0.008 & 0.008 & 0.008 & 0.008 & 0.010 \\
\hline 9 & Sekadau & - & - & - & 0.006 & 0.007 & 0.008 & 0.009 & 0.009 & 0.010 & 0.008 \\
\hline 10 & Melawi & - & - & - & - & 0.022 & 0.020 & 0.019 & 0.020 & 0.018 & 0.020 \\
\hline 11 & Kayong Utara & - & - & - & - & - & - & - & 0.003 & 0.002 & 0.002 \\
\hline 12 & Kubu Raya & - & - & - & - & - & - & - & 0.001 & 0.003 & 0.002 \\
\hline 13 & Ko. Pontianak & 0.007 & 0.007 & 0.007 & 0.008 & 0.008 & 0.010 & 0.010 & 0.010 & 0.011 & 0.009 \\
\hline 14 & Ko. Singkawang & - & 0.011 & 0.011 & 0.012 & 0.012 & 0.012 & 0.013 & 0.013 & 0.013 & 0.012 \\
\hline
\end{tabular}

Pada penelitian ini nilai kapasitas PAD estimasi didapatkan dari metode regresi dimana perbedaan dalam potensi keuangan pemerintah daerah dijelaskan lewat perbedaan dalam basis fiskalnya antara lain dari PDRB perkapita dan kontribusi sektor terhadap PDRB.

Selanjutnya dari nilai kapasitas PAD estimasi, maka akan didapatkan nilai upaya PAD. Upaya PAD dapat diartikan sejauh mana perekonomian suatu daerah menggunakan kapasitas PAD nya, sehingga upaya PAD dapat diukur dengan membandingkan antara kapasitas PAD (PAD/PDRB) aktual dengan kapasitas PAD (PAD/PDRB) estimasi yang didapatkan dari persamaan 8. Perbedaan antara nilai aktual dan estimasi dapat disebabkan kemampuan daerah dalam menggali sumber pendapatannya. 
Tabel 3. Upaya PAD Kabupaten/Kota di Propinsi Kalimantan Barat

\begin{tabular}{clccccccccc}
\hline \multirow{2}{*}{ No } & Kabupaten / & \multicolumn{9}{c}{ Kahun } \\
\cline { 3 - 11 } & \multicolumn{1}{c}{ Kota } & $\mathbf{2 0 0 1}$ & $\mathbf{2 0 0 2}$ & $\mathbf{2 0 0 3}$ & $\mathbf{2 0 0 4}$ & $\mathbf{2 0 0 5}$ & $\mathbf{2 0 0 6}$ & $\mathbf{2 0 0 7}$ & $\mathbf{2 0 0 8}$ & $\mathbf{2 0 0 9}$ \\
\hline 1 & Sambas & 0.9703 & 1.3363 & 1.0140 & 0.9454 & 0.7137 & 0.9821 & 0.8687 & 0.9020 & 1.0093 \\
2 & Bengkayang & 1.7215 & 1.1347 & 0.3581 & 0.7862 & 0.6638 & 1.2941 & 1.0681 & 0.8898 & 1.0683 \\
3 & Landak & 0.0204 & 0.0538 & 0.0639 & 0.0668 & 0.0782 & 0.3735 & 0.1084 & 0.1352 & 0.1649 \\
4 & Pontianak & 0.1099 & 0.1697 & 0.2218 & 0.2248 & 1.2930 & 1.5602 & 1.8528 & 1.6589 & 0.9783 \\
5 & Sanggau & 2.0083 & 1.6168 & 1.0030 & 1.1840 & 0.7089 & 0.7616 & 0.5627 & 0.8159 & 0.6972 \\
6 & Ketapang & 1.3729 & 1.0805 & 0.7551 & 0.8408 & 0.5631 & 1.2056 & 0.8913 & 1.2836 & 1.2643 \\
7 & Sintang & 2.1931 & 1.1740 & 0.5493 & 1.9729 & 0.3234 & 0.9075 & 0.6801 & 0.7064 & 0.8048 \\
8 & Kapuas Hulu & 1.2392 & 2.4246 & 0.5894 & 0.7299 & 0.5448 & 1.1017 & 0.4686 & 0.5461 & 0.6796 \\
9 & Sekadau & - & - & - & 0.1606 & 0.2377 & 1.0760 & 0.7809 & 1.3268 & 1.8639 \\
10 & Melawi & - & - & - & - & 0.2411 & 0.6359 & 0.8170 & 1.5743 & 1.8985 \\
11 & Kayong Utara & - & - & - & - & - & - & - & 0.3377 & 2.3348 \\
12 & Kubu Raya & - & - & - & - & - & - & - & 1.7575 & 1.1020 \\
13 & Ko. Pontianak & 0.7359 & 0.9598 & 0.9161 & 0.8592 & 0.9644 & 0.9135 & 1.1810 & 1.0952 & 1.0624 \\
14 & Ko. Singkawang & - & 0.2048 & 0.5237 & 0.4660 & 0.6064 & 1.2854 & 1.4293 & 1.5639 & 1.5649 \\
\hline
\end{tabular}

Keterangan:

Upaya PAD $=\frac{(\mathrm{PAD} / \mathrm{PDRB}) \text { aktual }}{(\mathrm{PAD} / \mathrm{PDRB}) \text { estimasi }}$

Selanjutnya dapat dilakukan analisis secara bersamaan antara kapasitas PAD dan upaya PAD seperti terlihat pada Grafik 3 - 11. Penggolongan kapasitas PAD mengacu kepada penelitian yang dilakukan oleh Luky (2003), dengan cara menggunakan batas rata-rata yang diperoleh setiap tahun. Kabupaten/Kota yang memiliki nilai kapasitas PAD lebih besar dari pada rata-rata tahun bersangkutan maka digolongkan tinggi dan jika nilai kapasitas PAD lebih kecil daripada rata-rata tahun bersangkutan maka digolongkan rendah.

Penggolongan upaya PAD menggunakan kriteria yang digunakan oleh Chelliah, Baas and Kelly (1975) dan Tait, Gratz and Eichengreen (1979) dalam Piancastelli (2001), dimana daerah dengan nilai upaya PAD lebih besar dari satu maka memiliki upaya PAD yang tinggi dan daerah dengan nilai upaya PAD lebih kecil dari satu maka memiliki upaya PAD yang rendah. Dengan penggolongan tersebut, maka akan didapatkan pemetaan setiap daerah pertahunnya seperti yang ditunjukkan pada Grafik 3 11

Pada Grafik 3 - 11 juga terlihat perkembangan upaya PAD tiap Kabupaten/Kota. Pada tahun 2001 hanya 5 dari 9 daerah yang tergolong memiliki upaya PAD yang tinggi kemudian pada tahun 2009 menjadi 9 dari 14 daerah yang upaya PAD nya tinggi. Tingginya upaya PAD suatu daerah mengindikasikan daerah tersebut dapat mengumpulkan PAD melebihi target yang hendak dicapai, dan ini dapat disebabkan oleh faktor ekonomi, sosial dan lembaga (Piancastelli, 2001). 


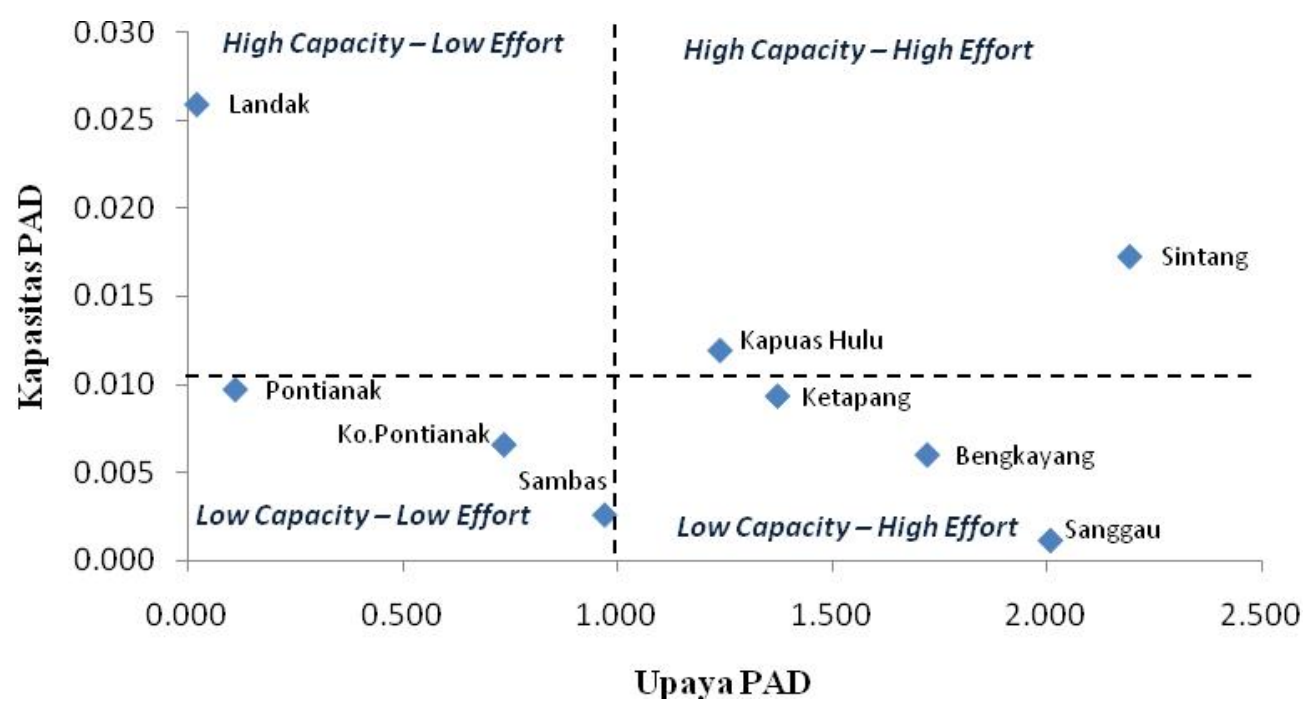

Grafik 3. Kapasitas PAD dan Upaya PAD Kabupaten/Kota di Propinsi Kalimantan Barat Tahun 2001

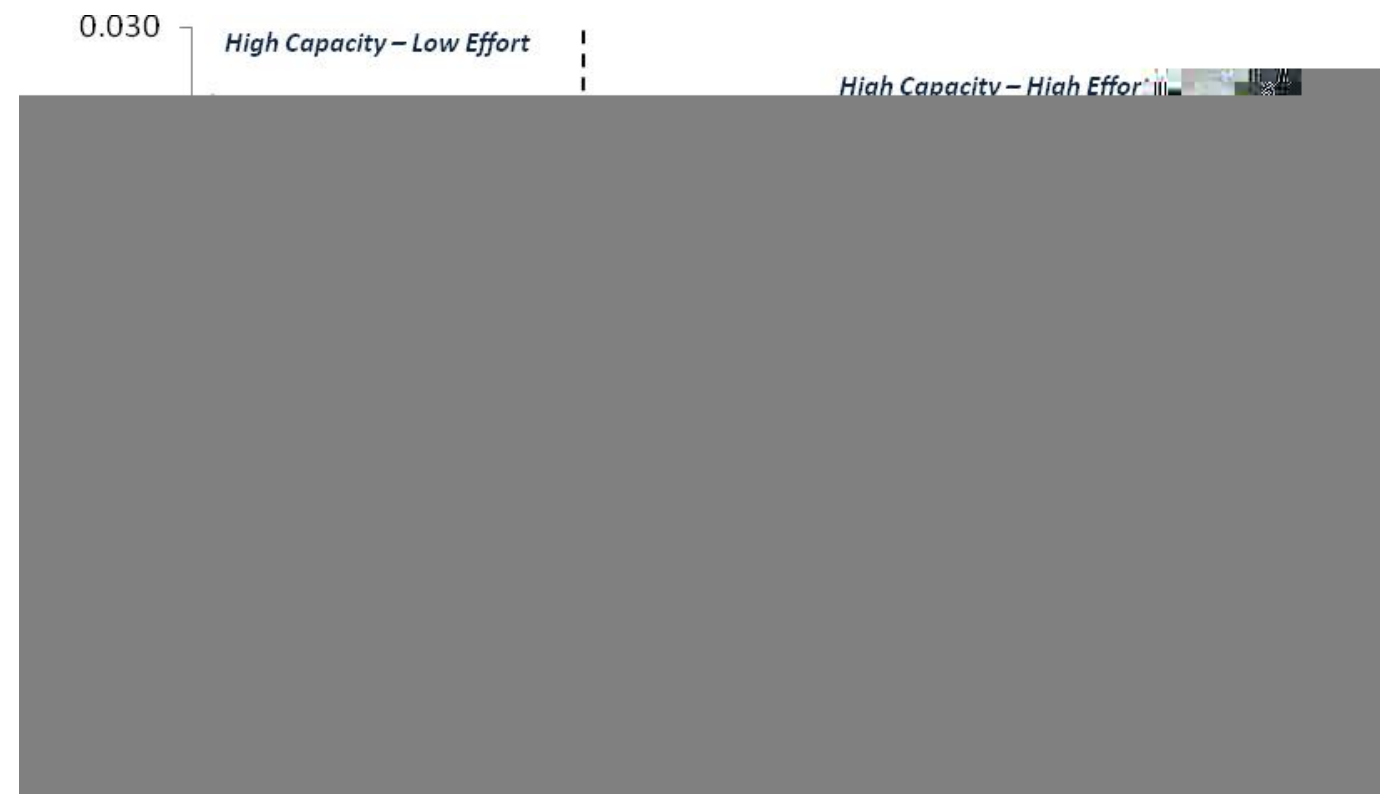

Grafik 4. Kapasitas PAD dan Upaya PAD Kabupaten/Kota di Propinsi Kalimantan Barat Tahun 2002 
Grafik 5. Kapasitas PAD dan Upaya PAD Kabupaten/Kota di Propinsi Kalimantan Barat Tahun 2003

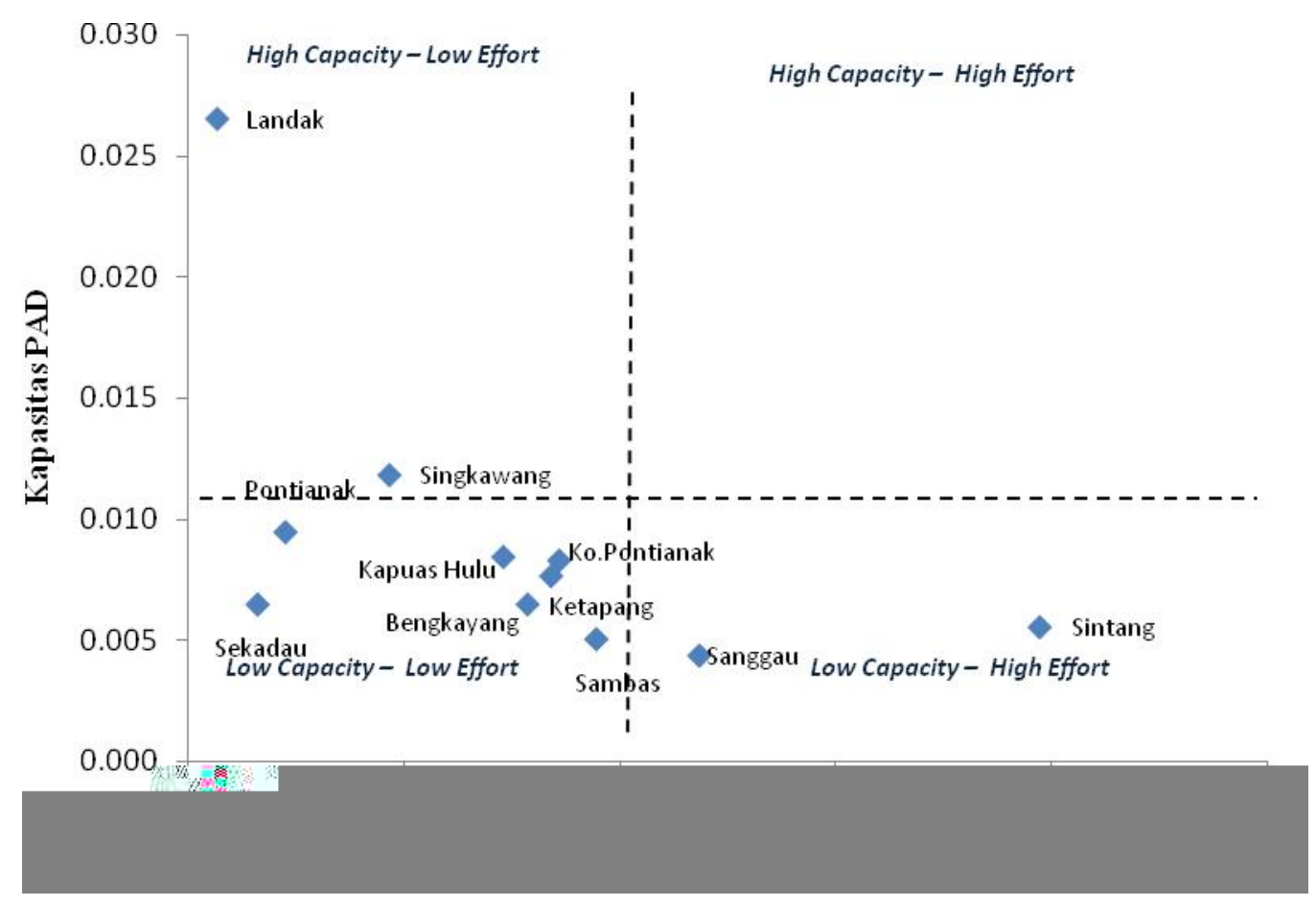

Grafik 6. Kapasitas PAD dan Upaya PAD Kabupaten/Kota di Propinsi Kalimantan Barat Tahun 2004 


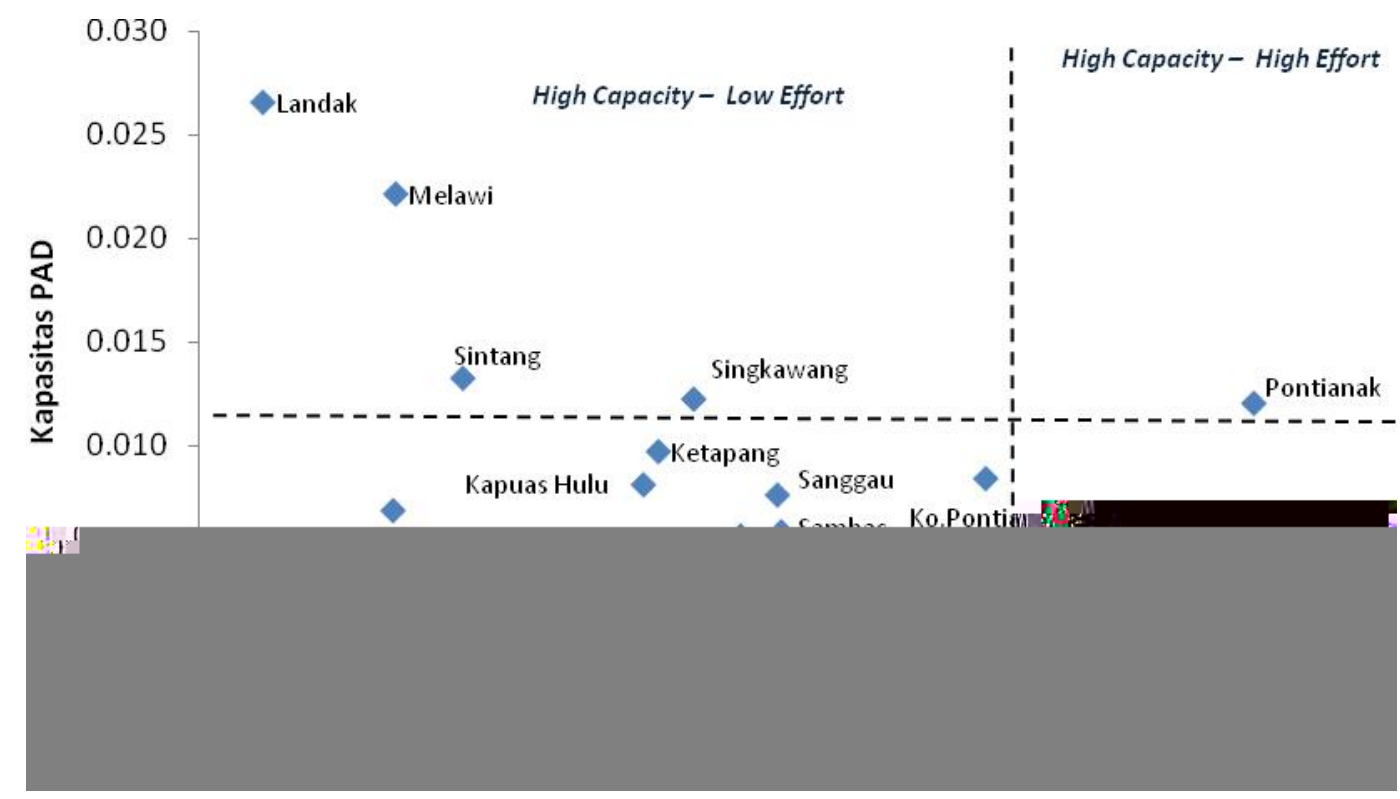

Grafik 7. Kapasitas PAD dan Upaya PAD Kabupaten/Kota di Propinsi Kalimantan Barat Tahun 2005

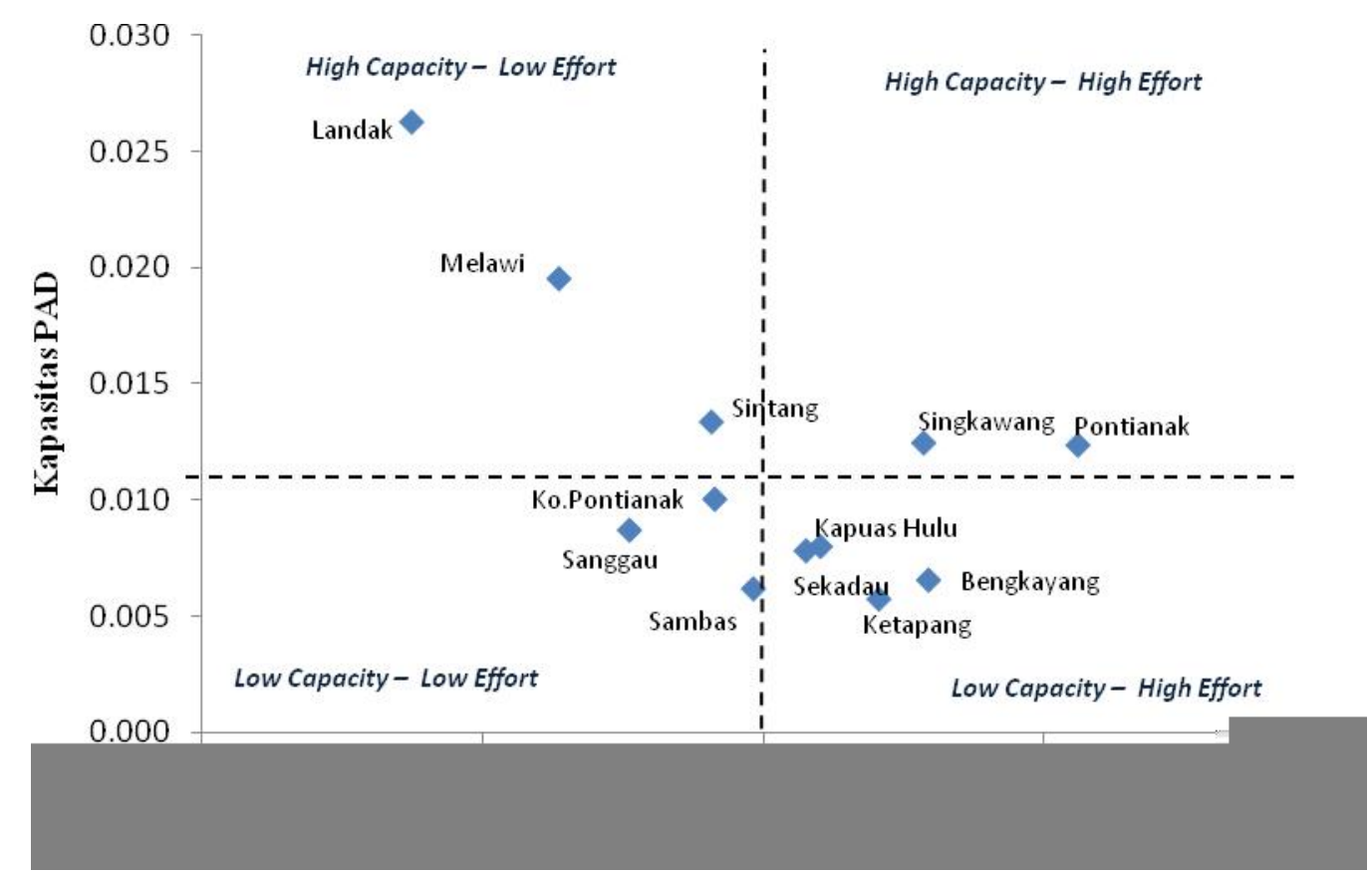

Grafik 8. Kapasitas PAD dan Upaya PAD Kabupaten/Kota di Propinsi Kalimantan Barat Tahun 2006 


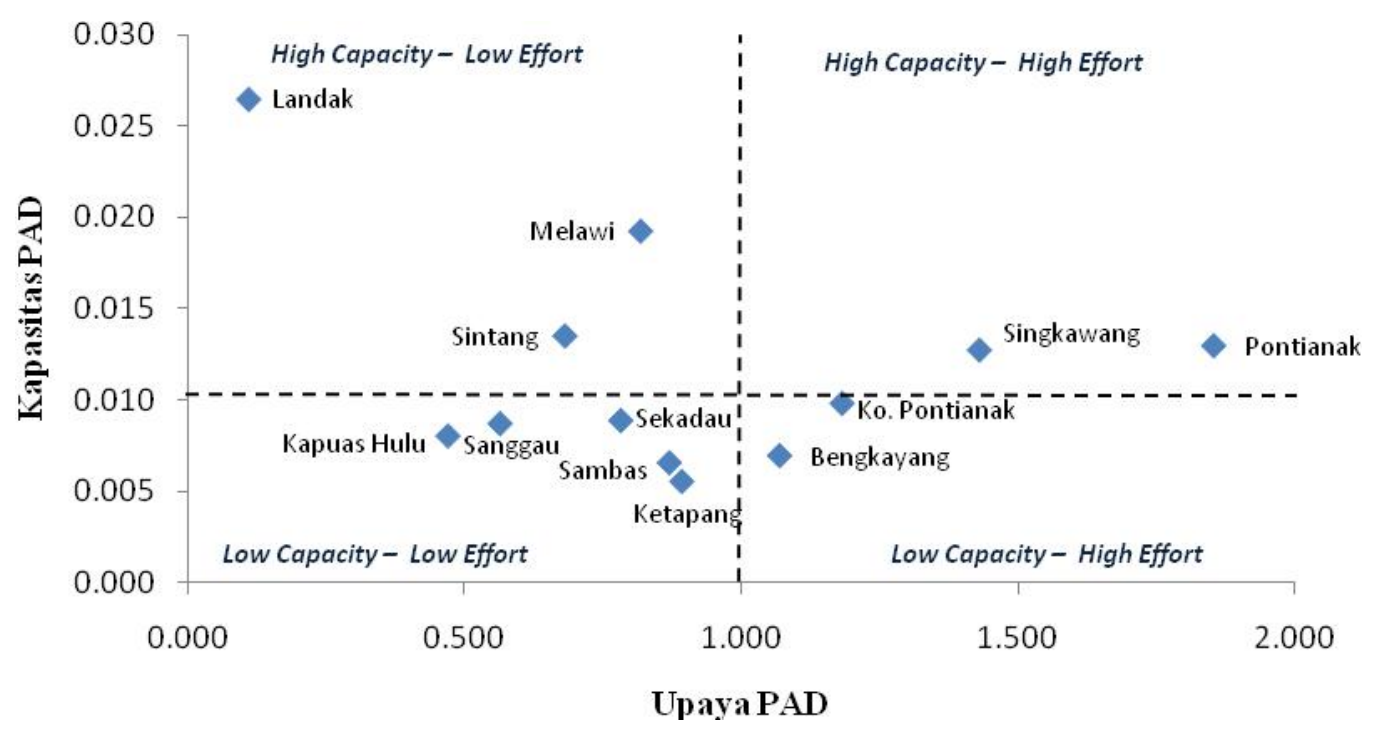

Grafik 9. Kapasitas PAD dan Upaya PAD Kabupaten/Kota di Propinsi Kalimantan Barat Tahun 2007

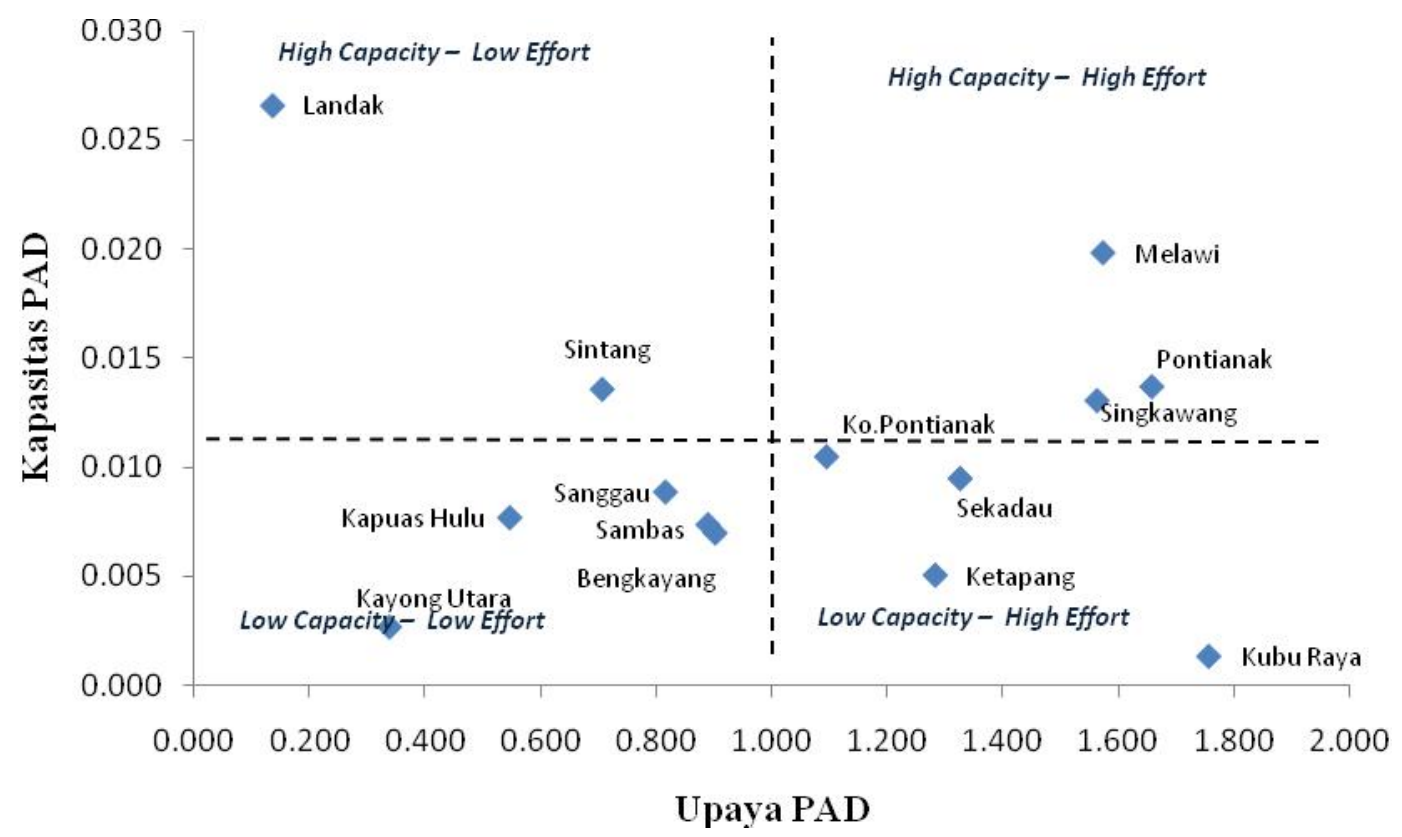

Grafik 10. Kapasitas PAD dan Upaya PAD Kabupaten/Kota di Propinsi Kalimantan Barat Tahun 2008 


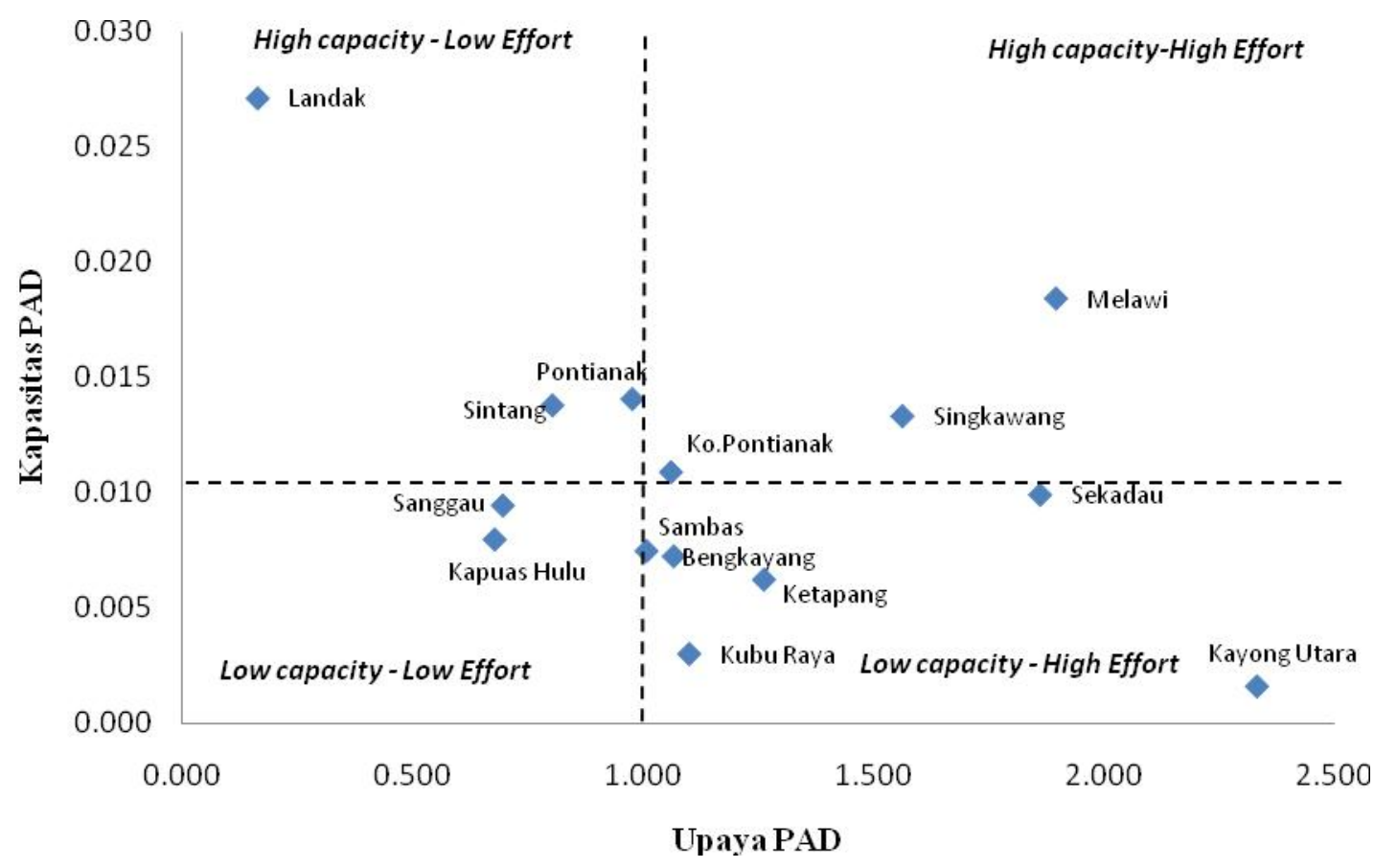

\section{Grafik 11. Kapasitas PAD dan Upaya PAD Kabupaten/Kota di Propinsi Kalimantan Barat Tahun 2009}

Pada Grafik 3 - 11 juga terlihat bahwa meskipun daerah tergolong dalam kapasitas dan upaya PAD yang sama tetapi nilainya berbeda. Hal ini dapat disebabkan oleh (1) upaya masing-masing daerah yang menunjukkan sejauh mana pemerintah setempat memanfaatkan kapasitas pendapatan yang ada (Gold, 1986 dalam Saruc \& Isa, 2008), (2) faktor endowment yang ada di setiap daerah Di Kabupaten/Kota Propinsi Kalimantan Barat.

Daerah yang tergolong high capacity - high effort menandakan daerah tersebut memiliki potensi ekonomi yang tinggi dan daerah tersebut mampu dalam memaksimalkan upaya dalam menggali kapasitas tersebut. Secara dominan, pada tahun 2001-2002 pada Kabupaten Sintang dan Kapuas Hulu. Tahun 2005-2007 pada Kabupaten Pontianak dan Kota Singkawang. Pada tahun 2008-2009 terdapat pada Kabupaten Melawi, Kota Singkawang dan Kota Pontianak. Pada ketiga daerah ini, kontribusi sektor perdagangan, hotel dan restoran paling besar dalam PDRB.

Daerah yang tergolong high capacity - low effort menandakan daerah tersebut belum optimal dalam menggali kapasitas pendapatan yang dimilikinya. Selama kurun waktu 9 tahun, Kabupaten Landak tergolong dalam klasifikasi ini. Adapun potensi ekonomi Kabupaten Landak antara lain pada sektor pertambangan (andesit dan granit), pertanian (padi, jagung, kacang hijau, kacang tanah, kedelai, lidah buaya, ubi jalar dan ubi kayu), perkebunan (kelapa sawit, kakao, karet, kopi dan kelapa), pariwisata. 
Daerah yang tergolong low capacity-high effort menandakan dengan kapasitas pendapatannya yang tidak terlalu besar tetapi daerah ini melakukan upaya yang tinggi dalam menggali potensi yang ada di daerahnya. Selama periode penelitian, Kabupaten Ketapang, Kabupaten Sambas dan Kabupaten Bengkayang dominan tergolong dalam klasifikasi ini. Untuk daerah yang tergolong low capacity - low effort menandakan dengan kapasitas pendapatannya yang tidak terlalu besar tetapi daerah ini juga tidak melakukan upaya yang maksimal. Selama tahun 2005-2009, Kabupaten Sanggau dominan tergolong dalam klasifikasi ini.

Upaya PAD dapat diketahui dengan melihat seberapa banyak daerah memperluas penerimaannya, dalam hal ini melalui pajak daerah dan retribusi daerah.Namun, suatu daerah dapat saja tergolong low effort walaupun jenis pajak daerah dan retribusi daerahnya melebihi daerah lain. Hal ini dikarenakan daerah tersebut hanya mengekstensifikasi pendapatannya tetapi tidak optimal dalam memungut pajak daerah dan retribusi daerahnya. Suatu daerah juga dapat tergolong high effort walaupun jenis pajak daerah dan retribusi daerahnya lebih sedikit dibandingkan daerah lainnya, disebabkan daerah tersebut melakukan intensifikasi pajak daerah dan retribusi daerah.

\subsubsection{Pengaruh PDRB Perkapita Terhadap Kapasitas PAD}

Pendapatan perkapita merupakan variabel yang sering digunakan oleh peneliti untuk mengetahui kapasitas pajak karena mencerminkan dasar pajak (tax base) negara/daerah (Suparmoko, 2002). Guritno (1993) menyatakan bahwa terdapat 3 ukuran yang mencerminkan kemakmuran yaitu pengeluaran konsumsi, kekayaan dan pendapatan perkapita. Ketiga ukuran tersebut mencerminkan tingkat kemakmuran juga menunjukkan kemampuan seseorang untuk membayar pajak.

Menurut Gujarati (2004), jika model lin-log maka elastisitasnya adalah

Dari hasil persamaan 8, diperoleh nilai koefisien regresi sebesar 0,0199, dengan nilai y sebesar 0,009 maka didapat elastisitasnya sebesar 2,3189. Artinya, rata-rata kecenderungan Kabupaten/Kota di Propinsi Kalimantan Barat dengan peningkatan PDRB perkapita sebesar 1\%, akan meningkatkan kapasitas PAD sebesar 2,32\%, ceteris paribus. Tanda positif pada koefisien menunjukkan adanya hubungan yang positif antara variabel PDRB perkapita dengan variabel kapasitas PAD.

Hasil dalam penelitian ini sejalan dengan teori dimana menurut Stotsky \& Asegedech (1997), Eltony (2002), Gupta (2007) dan Bird,et,al (2008) menyatakan bahwa pendapatan perkapita merupakan proksi dalam melihat berkembangnya perekonomian. Berkembangnya perekonomian berarti tingkat pembangunan lebih tinggi sehingga mengakibatkan kemampuan yang lebih tinggi untuk membayar dan mengumpulkan pajak. Luky (2003) dalam penelitiannya menyatakan bahwa tahap pembangunan (stage of development) merupakan fungsi dari ukuran dasar pajak (tax base) yang berarti negara-negara yang sedang giat membangun akan memperoleh pajak yang semakin besar dari yang diharapkan. 
Oleh karena terdapat hubungan positif antara tingkat pendapatan perkapita dengan kapasitas PAD, berarti jika PDRB perkapita mengalami kenaikan maka akan berdampak pula pada kenaikan kapasitas PAD yang diproksi dengan rasio PAD terhadap PDRB atau dapat dikatakan bahwa kenaikan PDRB perkapita dapat menstimulus kapasitas PAD.

\subsubsection{Pengaruh Sektor Perdagangan Terhadap Kapasitas PAD}

Pada hasil persamaan 8, diperoleh nilai koefisien regresi sebesar 0,0833. Artinya, rata-rata kecenderungan Kabupaten/Kota di Propinsi Kalimantan Barat dengan perubahan kontribusi sektor perdagangan terhadap PDRB sebesar 1\% akan mengakibatkan perubahan pada kapasitas PAD sebesar 0,0833 poin, ceteris paribus. Tanda positif pada koefisien menunjukkan adanya hubungan yang positif antara variabel perdagangan dengan variabel kapasitas PAD.

Hasil penelitian ini sesuai dengan penelitian-penelitian sebelumnya yang dilakukan oleh Piancastelli (2001), Ghura (1998) dan Lotz \& Morss (1967) dalam Gupta (2007). Paincastelli (2001) menyatakan perdagangan masih merupakan sumber penting penerimaan pajak terutama pada negara-negara berkembang sehingga ketika nilai perdagangan meningkat maka akan berpengaruh positif pada penerimaan pajak. Selain itu, pajak yang terkait dengan perdagangan lebih mudah untuk dikenakan karena barang akan keluar masuk dari satu daerah ke daerah lainnya. Kesimpulannya adalah sektor perdagangan memainkan peranan penting dalam meningkatkan kapasitas PAD.

\subsubsection{Pengaruh Sektor Pertanian Terhadap Kapasitas PAD}

Pada hasil persamaan 8, diperoleh nilai koefisien regresi sebesar 0,0555. Artinya, rata-rata kecenderungan Kabupaten/Kota di Propinsi Kalimantan Barat dengan perubahan kontribusi sektor pertanian terhadap PDRB sebesar $1 \%$ akan mengakibatkan perubahan pada kapasitas PAD sebesar 0,0555 poin, ceteris paribus. Tanda positif pada koefisien menunjukkan adanya hubungan yang positif antara variabel pertanian dengan variabel kapasitas PAD.

Hal ini sesuai dengan teori perkembangan struktur pajak dari Musgrave (1969), dimana struktur perekonomian menentukan struktur dari sistem pajak artinya struktur penerimaan pajak ini akan mengikuti pola basis pajak. Pada daerah yang struktur perekonomiannya masih didominasi oleh sektor pertanian akan sulit dalam mengenakan pajak pendapatan sehingga land tax dapat dijadikan sumber pendapatan utama. Oleh karena sektor pertanian masih mendominasi pada daerah Kabupaten/Kota di Propinsi Kalimantan Barat, maka sektor pertanian juga memiliki peranan penting terhadap kapasitas PAD. 


\subsection{Model Upaya PAD}

Dari hasil regresi model, didapatkan persamaan regresi model upaya PAD sebagai berikut :

$$
\begin{aligned}
& \mathrm{RE}_{\mathrm{it}}=1,9854+0.3052 \log U T_{i t}-0,1391 \log C T_{i t}+0.5023 \mathrm{PS}_{i t} \\
& \text { t-stat } \quad(1,5343) \quad(5,8038) * * * \quad(-3,6584) * * * \quad(1,6774) * \\
& \mathrm{R}^{2}=0,758214 \quad \text { F-stat }=17,05143 * * *
\end{aligned}
$$

Keterangan : $* * * \alpha=1 \%, * \alpha=10 \%$.

Dari persamaan 9, didapat nilai fixed effect (cross) untuk persamaan upaya PAD seperti yang tertera pada Tabel 4.

Tabel 4. Nilai Koefisien Fixed Effect Model Upaya PAD Di Kabupaten/Kota Propinsi Kalimantan Barat Tahun 2001 - 2009

\begin{tabular}{clc}
\hline No. & \multicolumn{1}{c}{ Kabupaten/ Kota } & Nilai Fixed Effect Pada Intersep \\
\hline 1. & Kab. Sambas & 0,042269 \\
2. & Kab. Bengkayang & 0,045970 \\
3. & Kab. Landak & $-0,698598$ \\
4. & Kab. Pontianak & $-0,072369$ \\
5. & Kab. Sanggau & 0,091050 \\
6. & Kab. Ketapang & 0,082204 \\
7. & Kab. Sintang & 0,088160 \\
8. & Kab. Kapuas Hulu & $-0,276040$ \\
9. & Kab. Sekadau & 0,453184 \\
10. & Kab. Melawi & 0,267446 \\
11. & Kab. Kayong Utara & 0,256865 \\
12. & Kab. Kubu Raya & 1,104942 \\
13. & Kota Pontianak & 0,054754 \\
14. & Kota Singkawang & $-0,124568$ \\
\hline
\end{tabular}

Upaya PAD pada Kabupaten/ Kota sangat berfluktuatif. Hal ini dapat dikarenakan jumlah realisasi PAD yang tidak sama setiap tahunnya dan keterbatasan yang dimiliki daerah dalam menentukan target PAD yang harus diperoleh berdasarkan potensi perekonomian daerahnya. Dari hasil regresi, terdapat sepuluh daerah Kabupaten/Kota yang mempunyai nilai fixed effect yang positif dapat diartikan bahwa jika variabel- variabel unconditional transfers (DAU dan DBH Pajak), conditional transfers (DAK), pelayanan publik (rasio jumlah PNS terhadap jumlah populasi) dianggap konstan maka indeks upaya PAD Kabupaten/ Kota tersebut akan meningkat sebesar nilai fixed effect kabupaten/kota tersebut. Perbedaan koefisien intercept antar daerah Kabupaten/Kota menunjukkan adanya perbedaan upaya PAD di masing-masing daerah, hal ini disebabkan antara lain (1) adanya perbedaan tingkat pelayanan publik di masingmasing daerah yang mengakibatkan jumlah PAD yang terkumpulkan pun berbeda, (2) perbedaan jumlah transfer pusat yang diterima setiap daerah yang berarti terdapat perbedaan kemampuan fiskal dan kebutuhan fiskal antar daerah, dan (3) adanya 
perbedaan karakteristik daerah. Selain itu menurut Piancastelli (2001), perbedaan intercept ini juga dapat disebabkan karena faktor budaya, lembaga dan batasan hukum ditiap daerah.

Upaya PAD di suatu daerah dapat dikatakan tinggi bilamana indeknya $>1$, dikatakan sedang jika indeknya antara 0,84-1 (1 > x > 0,84) dan dikatakan rendah jika indeknya $<$ 0,84 (Piancastelli, 2001). Tabel 5 merupakan klasifikasi upaya PAD Kabupaten/Kota menurut ukuran yang dikemukakan oleh Piancastelli (2001).

\subsubsection{Pengaruh Unconditional Transfers Terhadap Upaya PAD}

Dari persamaan 9, diperoleh nilai koefisien regresi $\propto_{1}$ sebesar 0,3052. Menurut Gujarati (2004), jika model lin-log maka elastisitasnya adalah $\beta\left(\frac{1}{x}\right)$. Dengan nilai $\mathrm{x}$ sebesar 0,9191 maka elastisitasnya sebesar 0,3321. Artinya, rata-rata kecenderungan Kabupaten/Kota di Propinsi Kalimantan Barat dengan kenaikan jumlah DAU dan DBH Pajak sebesar $1 \%$ akan mengakibatkan meningkatnya upaya PAD sebesar $0,33 \%$, ceteris paribus.

Dikarenakan nilai elastisitasnya lebih kecil dari 1, maka pengaruh unconditional transfer terhadap upaya PAD tergolong inelastis. Hal ini berarti besarnya perubahan upaya PAD yang dilakukan Pemerintah Daerah Kabupaten/Kota di Propinsi Kalimantan Barat tidak sebesar akibat perubahan jumlah transfer tak bersyarat yang diterima.

Stine (1994) mengemukakan bahwa ketika terjadi penurunan transfer maka pengeluaran daerah dan pendapatan sendiri (own-revenue) juga mengalami penurunan. Menurutnya, penurunan transfer menyebabkan turunnya dukungan pembiayaan kegiatan yang ditujukan untuk peningkatan pajak. Turunnya dukungan pembiayaan kemudian diantisipasi dengan peningkatan harga-harga layanan publik di tingkat lokal. Hal ini justru menjadi kontra produktif dikarenakan tidak menyebabkan terjadinya kenaikan pendapatan sendiri. Penerimaan sendiri justru mengalami penurunan karena publik merespon negatif peningkatan harga-harga layanan publik. Dapat disimpulkan dengan adanya transfer berarti menyebabkan adanya dukungan pembiayaan kegiatan yang ditujukan untuk peningkatan penerimaan daerah. Dimana dengan bertambahnya penerimaan maka daerah leluasa untuk mendesain kebijakan yang dapat memberikan stimulus pada pertumbuhan ekonomi.

Menurut Panggabean, et al., (1999), Secara teoritis dan empiris, DAU yang diterima daerah mampu menstimulasi ekonomi daerah lewat tiga cara. Pertama, alokasi DAU mampu mengurangi dampak negatif dari eksternalitas negatif yang ditimbulkan oleh daerah sekitarnya. Bila ini terjadi maka DAU sebenarnya memiliki kontribusi pada penciptaan efisiensi alokasi yang akhirnya akan menstimulasi ekonomi daerah. Kedua, lewat alokasi DAU maka daerah-daerah yang kekurangan modal akan bisa terbantu. Dengan demikian efek DAU adalah membantu menciptakan kombinasi input produksi yang lebih optimal. Artinya, DAU menstimulasi 
ekonomi daerah lewat efeknya terhadap perbaikan efisiensi produksi. Ketiga, alokasi DAU bisa didesain sedemikian rupa dikaitkan dengan upaya peningkatan PAD dan Bagi Hasil sehingga upaya penerimaan pajak, retribusi dan bagi hasil menjadi semakin meningkat. Bila ini terjadi, DAU akan memiliki kontribusi pada mobilisasi sumberdaya keuangan.

\section{Tabel 5. Klasifikasi Upaya Pendapatan Asli Daerah di Kabupaten/Kota Propinsi Kalimantan Barat}

\begin{tabular}{|c|c|c|c|c|c|}
\hline TAHUN & \multicolumn{2}{|c|}{ RENDAH } & SEDANG & \multicolumn{2}{|c|}{ TINGGI } \\
\hline 2001 & $\begin{array}{l}\text { Landak } \\
\text { Pontianak } \\
\text { Ko.Pontianak }\end{array}$ & & Sambas & $\begin{array}{l}\text { Bengkayang } \\
\text { Sanggau } \\
\text { Ketapang }\end{array}$ & $\begin{array}{l}\text { Sintang } \\
\text { Kapuas Hulu }\end{array}$ \\
\hline 2002 & $\begin{array}{l}\text { Landak } \\
\text { Pontianak }\end{array}$ & Singkawang & Ko.Pontianak & $\begin{array}{l}\text { Sambas } \\
\text { Bengkayang } \\
\text { Sanggau }\end{array}$ & $\begin{array}{l}\text { Ketapang } \\
\text { Sintang } \\
\text { Kapuas Hulu }\end{array}$ \\
\hline 2003 & $\begin{array}{l}\text { Bengkayang } \\
\text { Landak } \\
\text { Pontianak } \\
\text { Ketapang }\end{array}$ & $\begin{array}{l}\text { Sintang } \\
\text { Kapuas Hulu } \\
\text { Ko.Singkawang }\end{array}$ & Ko.Pontianak & $\begin{array}{l}\text { Sambas } \\
\text { Sanggau }\end{array}$ & \\
\hline 2004 & $\begin{array}{l}\text { Bengkayang } \\
\text { Landak } \\
\text { Pontianak }\end{array}$ & $\begin{array}{l}\text { Kapuas Hulu } \\
\text { Singkawang }\end{array}$ & $\begin{array}{l}\text { Sambas } \\
\text { Ketapang } \\
\text { Ko.Pontianak }\end{array}$ & $\begin{array}{l}\text { Sanggau } \\
\text { Sintang } \\
\text { Sekadau }\end{array}$ & \\
\hline 2005 & $\begin{array}{l}\text { Sambas } \\
\text { Bengkayang } \\
\text { Landak } \\
\text { Sanggau } \\
\text { Ketapang }\end{array}$ & $\begin{array}{l}\text { Sintang } \\
\text { Kapuas Hulu } \\
\text { Sekadau } \\
\text { Melawi } \\
\text { Singkawang }\end{array}$ & Ko.Pontianak & Pontianak & \\
\hline 2006 & $\begin{array}{l}\text { Landak } \\
\text { Sanggau } \\
\text { Melawi }\end{array}$ & & $\begin{array}{l}\text { Sambas } \\
\text { Sintang } \\
\text { Ko.Pontianak }\end{array}$ & $\begin{array}{l}\text { Bengkayang } \\
\text { Pontianak } \\
\text { Ketapang }\end{array}$ & $\begin{array}{l}\text { Kapuas Hulu } \\
\text { Sekadau } \\
\text { Singkawang }\end{array}$ \\
\hline 2007 & $\begin{array}{l}\text { Landak } \\
\text { Sanggau } \\
\text { Sintang }\end{array}$ & $\begin{array}{l}\text { Kapuas Hulu } \\
\text { Sekadau } \\
\text { Melawi }\end{array}$ & $\begin{array}{l}\text { Sambas } \\
\text { Ketapang }\end{array}$ & $\begin{array}{l}\text { Bengkayang } \\
\text { Pontianak }\end{array}$ & $\begin{array}{l}\text { Singkawang } \\
\text { Ko. Pontianak }\end{array}$ \\
\hline 2008 & $\begin{array}{l}\text { Landak } \\
\text { Sanggau } \\
\text { Sintang }\end{array}$ & $\begin{array}{l}\text { Kapuas Hulu } \\
\text { Kayong Utara }\end{array}$ & $\begin{array}{l}\text { Sambas } \\
\text { Bengkayang }\end{array}$ & $\begin{array}{l}\text { Pontianak } \\
\text { Ketapang } \\
\text { Sekadau } \\
\text { Melawi }\end{array}$ & $\begin{array}{l}\text { Kubu Raya } \\
\text { Singkawang } \\
\text { Ko. Pontianak }\end{array}$ \\
\hline 2009 & $\begin{array}{l}\text { Landak } \\
\text { Sanggau } \\
\text { Kapuas Hulu }\end{array}$ & & $\begin{array}{l}\text { Pontianak } \\
\text { Sintang }\end{array}$ & $\begin{array}{l}\text { Sambas } \\
\text { Bengkayang } \\
\text { Ketapang } \\
\text { Sekadau } \\
\text { Melawi }\end{array}$ & $\begin{array}{l}\text { Kayong Utara } \\
\text { Kubu Raya } \\
\text { Singkawang } \\
\text { Ko. Pontianak }\end{array}$ \\
\hline
\end{tabular}


Untuk DBH Pajak (Pajak Penghasilan, Pajak Bumi dan Bangunan, Bea Perolehan Hak Atas Bumi dan Bangunan), meskipun merupakan kewenangan pemerintah pusat, pemungutan pajak ini memerlukan sinergi antara pemerintah daerah setempat dengan kantor pelayanan pajak agar lebih optimal. Semakin tinggi penerimaan pajak-pajak ini di satu daerah, maka besarnya bagi hasil juga akan semakin tinggi. Selain itu terdapat insentif bagi daerah bila mampu melampaui target penerimaan pajaknya, seperti yang tertera pada PP No.55 Tahun 2005 tentang dana perimbangan.

\subsubsection{Pengaruh Conditional Transfers Terhadap Upaya PAD}

Dari persamaan 9, diperoleh nilai koefisien regresi $\propto_{2}$ sebesar $-1,391$, Menurut Gujarati (2004), jika model lin-log maka elastisitasnya adalah $\beta\left(\frac{1}{x}\right)$. Dengan nilai $\mathrm{x}$ sebesar 0,9191 maka elastisitasnya sebesar -0,1514. Artinya, rata-rata kecenderungan Kabupaten/Kota di Propinsi Kalimantan Barat dengan peningkatan jumlah DAK sebesar $1 \%$ akan mengakibatkan turunnya upaya PAD sebesar $0,15 \%$, ceteris paribus.

Dikarenakan nilai elastisitasnya lebih kecil dari 1, maka pengaruh conditional transfer terhadap upaya PAD tergolong inelastis. Hal ini berarti besarnya perubahan upaya PAD yang dilakukan Pemerintah Daerah Kabupaten/Kota di Propinsi Kalimantan Barat tidak sebesar dengan perubahan jumlah transfer bersyarat yang diterima.

Hal penelitian ini sesuai dengan fakta empirik di India dari Nagathan dan Sigvagnanam (1999) bahwa pemberian transfer yang terencana justru memberikan pengaruh negatif terhadap upaya pengumpulan pajak di tingkat lokal (daerah). Hasil yang serupa diungkapkan oleh Aragón \& Vilma (2005) untuk kasus di Peru, Sour (2007) dalam Bacarreza \& Nicolás (2010) dan Bacarreza \& Nicolás (2010) untuk kasus di Meksiko.

Dampak negatif dari conditional transfers antara lain menyebabkan Pemerintah Daerah memiliki ketergantungan yang tinggi terhadap transfer dari Pemerintah Pusat (Morales, 2006 dalam Bacarreza\& Nicolás, 2010) sehingga memiliki pengaruh negatif bagi upaya pendapatan daerah.

Pasal 162 UU No. 32/2004 menyebutkan bahwa DAK dialokasikan dalam APBN untuk daerah tertentu dalam rangka pendanaan desentralisasi untuk (1) membiayai kegiatan khusus yang ditentukan Pemerintah Pusat atas dasar prioritas nasional dan (2) membiayai kegiatan khusus yang diusulkan daerah tertentu.

Alokasi DAK untuk bidang pendidikan, kesehatan dan jalan lebih besar dibandingkan bidang lainnya pada semua Kabupaten/Kota di Propinsi Kalimantan Barat, mengindikasikan bahwa Pemerintah Pusat memberikan perhatian yang besar terhadap pembangunan pada tiga bidang tersebut dan memberikan informasi bahwa kondisi infrastruktur fisik dalam bidang-bidang tersebut untuk daerah Kabupaten/Kota di Propinsi Kalimantan Barat masih sangat diperlukan sehingga ketiganya memerlukan dana yang besar. 
DAK yang diberikan oleh Pemerintah Pusat didasarkan pada prioritas nasional yang tercantum dalam RK. Adapun jumlah bidang yang dibiayai DAK dari awal desentralisasi fiskal hingga tahun 2009 terus bertambah. Selanjutnya juga dapat dilihat bahwa bidang-bidang yang dibiayai DAK bukanlah bidang-bidang yang menjadi potensi penerimaan bagi daerah bahkan daerah juga dapat mengeluarkan biaya sehingga wajar jika DAK ternyata tidak dapat meningkatkan upaya PAD.

\subsubsection{Pengaruh Pelayanan Publik Terhadap Upaya PAD}

Dari hasil persamaan 9, nilai koefisien regresi sebesar 0,5023. Artinya, rata-rata kecenderungan Kabupaten/Kota di Propinsi Kalimantan Barat dengan perubahan 1\% pada rasio jumlah PNS terhadap jumlah populasi akan mengakibatkan naiknya upaya PAD sebesar 0,5023 poin, ceteris paribus.

Rasio PNS terhadap populasi memiliki pengaruh yang positif dengan asumsi semakin banyak PNS khususnya di Dinas Pendapatan Daerah maka semakin tinggi pula upaya dalam mengumpulkan PAD sehingga PAD pun meningkat.Berikut dapat dilihat trend jumlah PNS dan PAD untuk beberapa Kabupaten/Kota.

Stine (1994) mengasumsikan bahwa pejabat publik daerah dapat menerapkan berbagai kebijaksanaan dalam menentukan besaran dan komposisi dari pendapatan daerahnya. Alasannya adalah dalam menyediakan pelayanan publik, pejabat daerah dianggap memahami preferensi masyarakatnya. Selanjutnya, Adams (1966) menyatakan bahwa upaya fiskal suatu daerah bervariasi sesuai dengan kebutuhan dalam pelayanan publiknya. Oleh karenanya, pelayanan publik yang dilakukan oleh pemerintah daerah setempat akan meningkatkan upaya penerimaan daerahnya.

\section{KESIMPULAN}

Terdapat tiga kesimpulan yang dapat ditarik dari temuan penelitian ini. Pertama, terdapat perbedaan dalam kapasitas PAD Kabupaten/Kota di Propinsi Kalimantan Barat, sehingga menyebabkan upaya $\mathrm{PAD}$ pun berbeda. Kedua, secara rata-rata pada Kabupaten/ Kota di Propinsi Kalimantan Barat, DAU dan DBH Pajak (unconditional transfers) serta pelayanan publik memiliki pengaruh positif dan signifikan terhadap upaya Pendapatan Asli Daerah. Ketiga, secara rata-rata pada Kabupaten/Kota di Propinsi Kalimantan Barat, DAK (conditional transfers) berpengaruh negatif signifikan terhadap upaya Pendapatan Asli Daerah.

Untuk penelitian selanjutnya, pertama, dapat menambahkan beberapa variabel independen dalam menggambarkan kapasitas pendapatan suatu daerah (misalnya: variabel jumlah rumah tangga menurut sektor perekonomian, dan banyaknya fasilitas penunjang kegiatan ekonomi seperti: jumlah bank, sekolah, fasilitas kesehatan, infrastruktur) serta dapat menambahkan variabel independen dalam menggambarkan upaya PAD (misalnya: variabel rasio jumlah pegawai Dinas Pengelolaan Keuangan dan 
Aset Daerah terhadap jumlah populasi sebagai indikator dalam meningkatkan upaya pendapatan asli daerah, variabel kebijakan daerah, dan variabel biaya dalam pemungutan pajak). Kedua, DAU dan DBH Pajak (unconditional transfers) harus lebih baik dalam proses perencanaan, pengalokasian, pencairan serta penggunaannya sehingga tetap berdampak positif terhadap upaya PAD. Ketiga, DAK (conditional transfers) kedepan sebaiknya menggunakan pendekatan pencapaian output dan tidak menggunakan dana pendamping, sehingga sesuai dengan taxonomy of grants (Shah, 2007) akan menghasilkan akuntabilitas dan kesejahteraan yang lebih tinggi bagi daerah.

\section{DAFTAR PUSTAKA}

Adams, R. F. (1966). The Fiscal Response to Intergovernmental Transfers in Less Developed Areas of the United States. The Review of Economics and Statistics, 48(3), 308-313.

Aragón, F. M. \& Vilma J. G. (2005). Intergovernmental Transfers and Fiscal Effort in Peruvian Local Governments. Munich Personal RePEc Archive (MPRA) Paper No. 2108.

Bacarreza, G. C. \& Nicolás G.Z. (2010). Fiscal Transfers a Curse or Blessing? Evidence of Their Effect on Tax Effort for Municipalities in Sinaloa, Mexico. Working Paper 10-30, Georgia State University.

Besfamille, M. \& Pablo S. (2004). Exerting Local Tax Effort Or Lobbying For Central Transfers?. Universidad Torcuato Di Tella. Argentina.

Badan Pusat Statistik, Provinsi Kalimantan Barat. (2009). Kalimantan Barat Dalam Angka. Pontianak: BPS Provinsi Kalimantan Barat.

Badan Pusat Statistik, Provinsi Kalimantan Barat. (2010). Kalimantan Barat Dalam Angka. Pontianak: BPS Provinsi Kalimantan Barat.

Brun, J. F., Gérard, C. \& Bertrand, L. (2010). IMF programs and tax effort, What role for institutions in Africa?. CERDI, Etudes et Documents, E 2010.33.

Chaparro, J. C., Smart, M. \& Zapata, J. G. (2004). Intergovernmental Transfers and Municipal Finance in Columbia. ITP Paper 0403. University of Toronto.

Departemen Keuangan Republik Indonesia. (2011). Data Pokok APBN 2005-2010., 2011, http://www.anggaran.depkeu.go.id/Content/10-01-07,\%20Data\%20Pokok \%20 Indorev1.pdf. Diakses pada 2 Febuari 2014.

Eltony, M. N. (2002). The Determinants of Tax Effort in Arab Countries. Arab Planning Institute. Kuwait. 
Gamkhar, S. \& Anwar S. (2007). The Impact of Intergovernmental Transfers. In R. Boadway and A. Shah (eds.), Intergovernmental Fiscal Transfers (pp. 225-258). Washington, D.C: The World Bank.

Gupta, A. S. (2007). Determinant of Tax Revenue Effort in Developing Countries. IMF Working Paper, WP/07/184. IMF, Washington.

Gujarati, D. N. (2004). Basic Econometrics Fourth Edition. Singapore : McGraw-Hill.

Guritno M. (1993). Ekonomi Publik Edisi 3.Yogyakarta : BPFE.

Haryo, K. (2004). Pengaruh Transfer Antar Pemerintah Pada Kinerja Fiskal Pemerintah Daerah Kota dan Kabupaten di Indonesia. Jurnal Ekonomi Pembangunan, 9 (1), 47-63.

Jha, R. Woojin, K. \& Nagarajan, H. K. (2011). Fiscal Decentralization and Local Tax Effort. ASARC Working Paper 2011/01.

Luky, A. (2003). Estimating Stochastic Frontier Tax Potential : Can Indonesian Local Government Increase Tax Revenue Under Decentralization?. Working Paper No. 03-19. University of Colorado.

Machfud, S. (2002). Format Hubungan Keuangan Pemerintah Pusat dan Daerah yang Mengacu Pada Pencapaian Tujuan Nasional. Seminar Nasional "Public Sector Scorecard", Jakarta.

Musgrave, R. A. (1969). Fiscal Systems. New Haven and London: Yale University Press.

Musgrave, R. A. \& Peggy B. M. (1989). Public Finance in Theory and Practice. McGraw-Hill International Editions.

Naganathan, M \& K. Jothi S. (2000). Federal Transfers and Tax Efforts of the States in India. Indian Economic Journal, 47 (4), 101-110.

Oates, W. E. (2005). Toward A Second-Generation Theory of Fiscal Federalism. International Tax and Public Finance, 12, 349-373.

Panggabean, A. Mahi, B. R., Panggabean, M. \& Brodjonegoro, B. P. S. (1999). Distribusi Dana Alokasi Umum (DAU): Konsep dan Formula Alokasi. Jakarta: IUC-Economics-UI.

Peraturan Pemerintah Republik Indonesia Nomor 55 Tahun 2005, Tentang Dana Perimbangan.

Piancastelli, M. (2001). Measuring The Tax Effort of Developed and Developing Countries. Cross Country Panel Data Analysis - 1985/95. IPEA, Rio de Janeiro.

Rosen, H. S. \& Gayer, T. (2010). Public Finance Ninth Edition. Singapore: McGraw Hill. 
Saruc, N. T. \& Isa S. (2008). The Surge Impact of the Flypaper, Substitution and Stimulation Effect on Local Tax Effort in Turkey. International Research Journal of Finance and Economics, Issue 13.

Shah, A. (2007). A Practitioner's Guide to Intergovernmental Fiscal Transfers. In R. Boadway and A. Shah (eds.), Intergovernmental Fiscal Transfers (pp.1-53). Washington, D.C : The World Bank.

Stine, W. (1994). Is the Local Government Revenue Response to Federal Aid Symmetrical? Evidence From Pennsylvania County Government in an Era of Retrenchment. National Tax Journal, 47 (4),799-816.

Stotsky, J. G \& Asegedech W. M. (1997). Tax Effort in Sub-Saharan Africa. IMF Working Paper. WP/97/107.

Suparmoko. (2002). Ekonomi Publik Untuk Keuangan dan Pembangunan Daerah. Yogyakarta: Penerbit ANDI.

Undang-Undang Republik Indonesia Nomor 32 Tahun 2004, Tentang Pemerintahan Daerah. 